Article

\title{
Electrical Energy Producing Greenhouse Shading System with a Semi-Transparent Photovoltaic Blind Based on Micro-Spherical Solar Cells
}

\author{
Zhi Li ${ }^{1}$, Akira Yano ${ }^{2, *}$, Marco Cossu ${ }^{3}$, Hidekazu Yoshioka ${ }^{2}$, Ichiro Kita ${ }^{2}$ and Yasuomi Ibaraki ${ }^{4}$ \\ 1 The United Graduate School of Agricultural Sciences, Tottori University, 4-101 Koyama-Minami, \\ Tottori 680-8553, Japan; 1_izhi@yahoo.co.jp \\ 2 Institute of Environmental Systems Science, Shimane University, 1060 Nishikawatsu, Matsue, \\ Shimane 690-8504, Japan; yoshih@life.shimane-u.ac.jp (H.Y.); kita@life.shimane-u.ac.jp (I.K.) \\ 3 Department of Agriculture, University of Sassari, Viale Italia 39, 07100 Sassari, Italy; \\ dr.marcocossu@gmail.com \\ 4 Faculty of Agriculture, Yamaguchi University, 1677-1 Yoshida, Yamaguchi 753-8515, Japan; \\ ibaraki2@yamaguchi-u.ac.jp \\ * Correspondence: yano@life.shimane-u.ac.jp; Tel.: +81-852-32-6543
}

Received: 4 June 2018; Accepted: 26 June 2018; Published: 27 June 2018

\begin{abstract}
An increasing population and limited arable land area endanger sufficient and variegated food supplies worldwide. Greenhouse cultivation enables highly intensive plant production and thereby enables the production of abundant fresh vegetables and fruits. The salient benefits of greenhouse cultivation are supported by ingenious management of crop environments, assisted by fossil fuel and grid electricity supplies. To reduce dependence on traditional energy resources, various studies have investigated exploitation of renewable energies for greenhouse environment management. Among them, solar photovoltaic (PV) technologies are anticipated to feed electrical energy to greenhouse appliances for microclimate control. This study proposes a venetian-blind-type shading system consisting of semi-transparent PV modules as blind blades based on micro-spherical solar cell technology to achieve greenhouse shading and electricity production concurrently. In response to the solar irradiance level, the PV blind inclination was altered automatically using a direct current (DC) motor driven by electrical energy generated by the PV blind itself. The PV blind was operated continuously during a five-month test period without outage. Moreover, the PV blind generated surplus electrical energy of $2125 \mathrm{~kJ}$ for blind system operations during the test period. The annual surplus energy calculated under the present experimental condition was $7.8 \mathrm{kWh} \mathrm{m}^{-2}$ year $^{-1}$, suggesting that application of the PV blind to a greenhouse roof enables sunlight level control and electrical appliance operations in the greenhouse with a diminished fuel and grid electricity supply, particularly in high-insolation regions.
\end{abstract}

Keywords: cultivation; food supply; sunlight; plant; renewable energy; solar energy; stand-alone; venetian-blind

\section{Introduction}

Greenhouse cultivation allows intensive plant production supported by ingenious management of crop environments, assisted with fossil fuel and grid electricity supplies. Demands for fuel and electricity have increased as growers strive to improve crop yield and quality and to extend cultivation seasons and geography, partly because of expectations to feed the increasing populations [1]. As the dependence on fuel and grid electricity increases, the risk of losing stability of growers' profits increases because of the fluctuating prices of energy resources. Furthermore, the use of fossil fuels 
produces carbon dioxide emissions, the amounts of which should be reduced in the agricultural sector [2]. Under these circumstances, various studies have been conducted to use renewable energy for managing greenhouse crop environments [3,4]. Among them, solar photovoltaics (PVs) are expected to feed electricity to appliances that are used for greenhouse environment management [5].

Deploying PV arrays on the sunny ground beside a greenhouse is the simplest and most effective mode of electrical energy generation. For instance, fan and pad cooling systems in Saudi Arabia [6] and in Arizona [7], a fog cooling system in Malaysia [8], and heat pump systems in Italy $[9,10]$ were operated with power from ground-mounted PV arrays. Nevertheless, installing PV arrays partially on a greenhouse roof might be preferred if the PV panels are intended as shading materials. Shading is a fundamentally important practice for greenhouse cultivation in high-insolation regions, such as Spain [11] or Saudi Arabia [12]. Previous studies conducted in Japan [13] and in the Mediterranean region $[14,15]$ demonstrated that an adequate level of shading mitigates excessive temperature rises in greenhouses in summer, improving crop growth and quality $[16,17]$. Conventionally, nets $[14,15,18]$ and reflective coatings $[18,19]$ have been used as practical and reasonable methods for greenhouse shading. Sunlight on the canopy is moderated properly by virtue of the reflection of partial solar irradiance to the outside using these simple shading methods. The sunlight energy reflected in the greenhouse roof to the outside is discarded because it has no role for cultivation.

The installation of semi-transparent PV modules on a greenhouse roof surface can be beneficial when crops require moderate shading under high-irradiation conditions. Those semi-transparencies vary from checkerboard formations of conventional planar PV modules [20-22] or cells [23-25] to dispersed PV micro-cells [26,27]. In this way, appropriate levels of shading and electricity generation can be achieved concurrently. For example, some reported studies have demonstrated that Welsh onion [28], tomato [29,30], lettuce [31-34], and wild rocket [35] were cultivated properly under the semi-transparent PV panels. Accordingly, solar-radiation use efficiency in the greenhouse would be increased by the use of PV-generated electrical energy for cultivation environment management.

Another concept related to the use of PVs in greenhouse roofs is partitioning of the wavelength ranges of the solar radiation spectrum for electrical energy generation and crop cultivation using infrared reflective film [36,37], organic PV cells [38-40], dye-sensitized PV cells [41,42], or dichroitic polymer film [43]. In this way, photosynthetically active radiation can be transmitted into the greenhouse for cultivation, but the remaining wavelength range of solar radiation is useful for generating electricity. In earlier studies, Fresnel lenses were used in greenhouse roof installations to concentrate direct sunlight onto PV modules for electricity generation and to pass scattered sunlight for crop cultivation [44,45].

Recently, PV blind systems have been proposed for dynamic control of irradiance in greenhouses. Vadiee and Martin [46] proposed a solar blind concept in which the numbers of PV/thermal modules rotate according to a greenhouse temperature set-point. On a theoretical basis, they estimated that more than $1 \mathrm{TWh}_{\text {year }}{ }^{-1}$ of external energy demand in the Swedish agricultural sector can be reduced by replacing all conventional greenhouses with closed greenhouses integrated with the solar blind system. Additionally, they estimated that $70 \mathrm{kWh} \mathrm{m}^{-2}$ year $^{-1}$ of electricity would be producible by exploiting the solar blind system in Iranian greenhouses [47]. The blind operations can reduce both heating and cooling demand, thereby reducing the total energy consumption of the greenhouses [48,49]. In Italy, Marucci et al. [50] and Marucci and Cappuccini [51,52] developed a greenhouse PV blind system accompanied by mirrors for increasing the light-collection efficiency for electricity generation. The system performance was tested in an experimental model greenhouse. The shading pattern inside the greenhouse was documented. Although room exists for improving the PV blind structures and controllability to achieve an optimum balance between the shading percentage and electricity production, theoretically speaking, such a PV blind system can realize stand-alone greenhouse crop production, in energy terms, in high-insolation regions.

As summarized briefly above, applications of PV cells for greenhouse cultivations are emerging. They have become increasingly sophisticated with the advancement of PV cell technologies [53]. 
Among them, dynamic regulation of greenhouse-roof PV shading is expected to provide a better balance between crop cultivation and electricity production. In fact, the performance can be improved further by exploiting semi-transparent PV technologies. For this reason, we developed a greenhouse venetian-blind-type shading system in this study using semi-transparent PV modules as blind blades. The PV blind characteristics and the energetic performances of the PV blind operations are reported herein.

Active blind-type shading systems have been investigated widely for building applications [54]. However, such systems have been investigated only rarely for greenhouse applications, although shading control is extremely important in greenhouse cultivations [12]. In the present manuscript, a novel PV blind system specific for greenhouse applications is presented. The system is designed with an automatic blind-angle control in response to the solar irradiance level at the greenhouse site. The PV blind can rotate parallel or perpendicular to the greenhouse roof, according to desired and pre-chosen irradiation levels. This function enhances the efficacy of the reported PV blind systems [51,52], providing more hospitable cultivation conditions in greenhouses under fluctuating sky conditions. The semi-transparency of the PV blind provides the benefits of sunlight availability to crops. Moreover, the energy generated by the PV blind can compensate the electricity demands for greenhouse environment management in addition to the PV blind operations.

\section{Development and Operational Testing of the Prototype PV-Blind System}

\subsection{Bifacial Semi-Transparent PV Modules Used as Blind Blades}

The prototype PV blind had three semi-transparent PV modules as blind blades (Figure 1). For this study, only three identical PV modules were assembled because of the difficulty of manufacturing the special semi-transparent PV modules, which thereby increased manufacturing costs. The specifications of the PV modules are presented in Table 1. In the bifacial PV module, numerous spherical micro-PV cells (Sphelar ${ }^{\circledR}$; Sphelar Power Corp., Kyoto, Japan) were embedded in the transparent resin layer with conductor wires ( $0.38 \mathrm{~mm}$-wide and $0.1 \mathrm{~mm}$-diameter) connecting each cell [55]. The PV cells were aligned between the conductors (Figure 1a), which draw generated electric power to the external circuit. Each cell had a p-type semiconductor inner core coated with an n-type semiconductor outer shell $[26,27,55-57]$. The see-through semi-transparency is a particular merit of using the dispersed numerous micro-PV cells. Between a pair of the linear conductors, 62 PV cells were aligned (Figure 1a). This arrangement was repeated 74 times in the $154 \mathrm{~mm} \times 158 \mathrm{~mm}$ rectangular area. Each PV module had three rectangular semi-transparent areas. The odd and even lines of the cell series were defined as $a_{\mathrm{i}}$ and $b_{\mathrm{i}}(i=1-37)$, respectively. The 124 cells in each $a_{\mathrm{i}}$ and $b_{\mathrm{i}}$ pair were connected electrically in parallel. The 37 pairs of $a_{\mathrm{i}}$ and $b_{\mathrm{i}}$ were connected in series. The cell arrangements in the three rectangular areas were connected in parallel to constitute the $1.2 \mathrm{~W}$ rated power per single PV module. Finally, the electricity output terminals of the three PV modules were connected in parallel.

The PV module rim was enclosed within an aluminum frame. Three PV modules were aligned on the common rotation axis (Figure 1b). A shaft joined the PV modules and a geared direct current (DC) motor (SS23F-LH-860-DC12V; Sawamura Denki Ind. Co., Ltd., Kanagawa, Japan) with rated specifications of $12 \mathrm{~V}$ voltage, $0.3 \mathrm{~A}$ current, $2.0 \mathrm{~N} \mathrm{~m}$ torque, and $4 \mathrm{rpm}$ rotation speed. The PV modules were supported with a $1872 \mathrm{~mm} \times 825 \mathrm{~mm}$ frame. Two pyranometers, $\mathrm{P}_{\mathrm{PVT}}$ and $\mathrm{P}_{\mathrm{PVB}}$ (ML-01; Eko Instruments Co. Ltd., Tokyo, Japan), were installed proximally at the long side of the central PV module (Figure 1b). The accuracy of the pyranometer was $\pm 1.70 \%$ for irradiance measurements. The $\mathrm{P}_{\mathrm{PVT}}$ aligned as its normal coincided with the PV module normal to measure global irradiance on the PV top surface $I_{\mathrm{PVT}}$. The $\mathrm{P}_{\mathrm{PVB}}$ directed $180^{\circ}$, thereby aligned as opposite, measured global irradiance on the PV back surface $I_{\mathrm{PVB}}$. A pyranometer $\mathrm{P}_{\mathrm{Cell}}$ was installed at $0.2 \mathrm{~m}$ below the PV module with its normal direction aligned to the PV module normal. $\mathrm{P}_{\text {Cell }}$ measured the irradiance in the semi-transparent PV module shadow $I_{\text {Cell }}$ to determine the sunlight transmittance of the PV blind. 


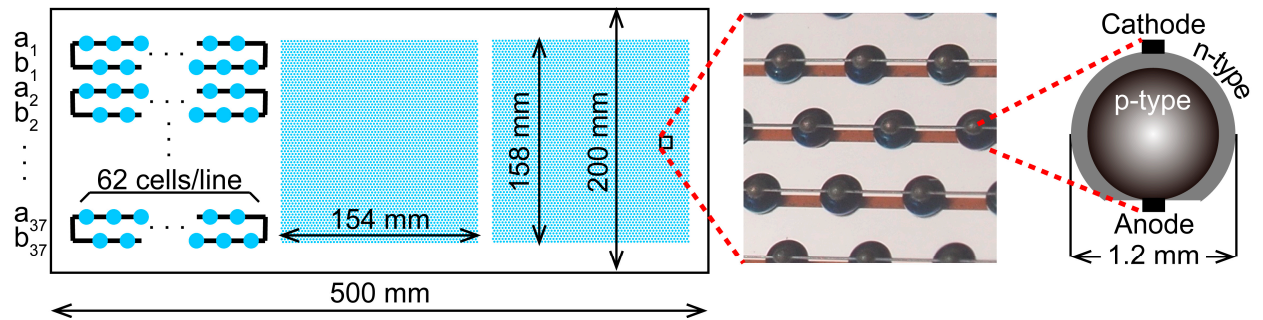

(a)

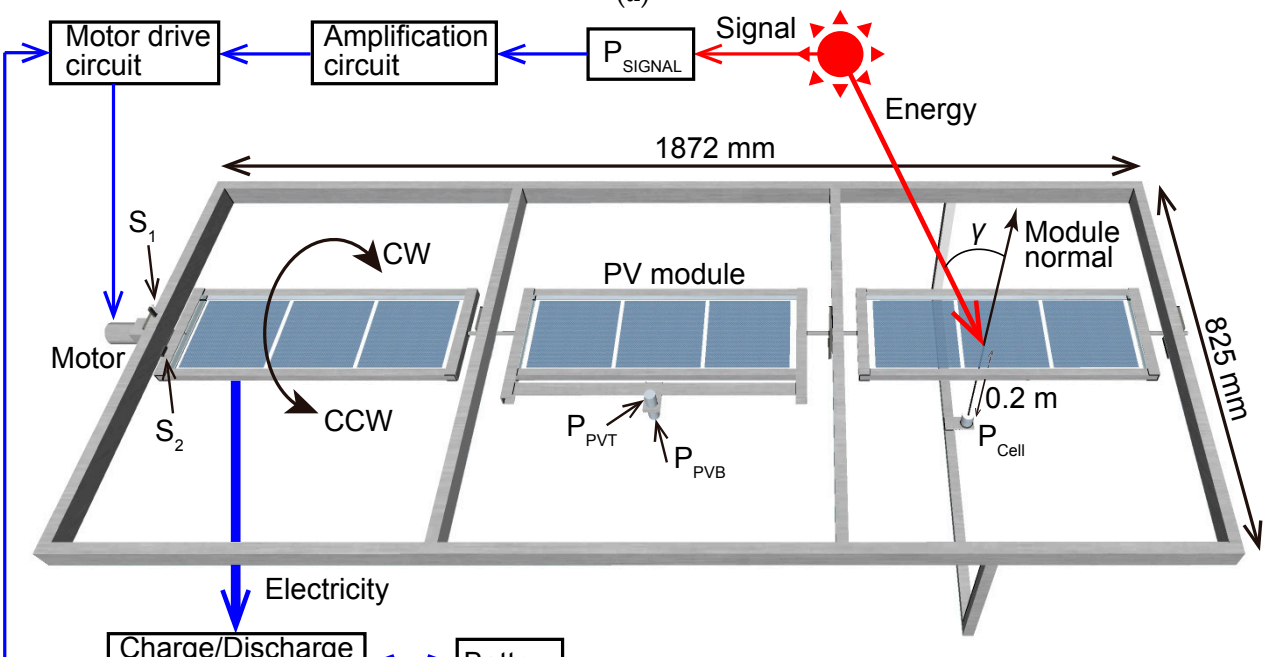

(b)

Figure 1. Semi-transparent photovoltaic (PV) module as a venetian-blind-blade for the greenhouse shading application: overview of the PV module with close-up photograph and cross-sectional structure of the spherical Si-PV cell; (a): block diagram of the prototype PV blind system (b): $\mathrm{P}_{\mathrm{PVT}}$ and $\mathrm{P}_{\mathrm{PVB}}$ are pyranometers facing opposite directions to measure the total incident irradiance on the bifacial PV module. $S_{1}$ and $S_{2}$ are mechanical switches to stop the module rotation at the perpendicular or parallel position to the greenhouse roof when the module contacts with $S_{1}$ or $S_{2}$. CW-clockwise; CCW—counter-clockwise.

Table 1. Specifications of the semi-transparent photovoltaic (PV) module used as the blind blade

\begin{tabular}{|c|c|}
\hline Dimensions & $500 \mathrm{~mm} \times 200 \mathrm{~mm} \times 11 \mathrm{~mm}$ \\
\hline Weight per module & $2.23 \mathrm{~kg}$ \\
\hline Cross-sectional structure & $\begin{array}{l}3.8 \mathrm{~mm} \text { glass plate } / 3.0 \mathrm{~mm} \text { resin including the cells } \\
\text { and conductors } / 3.8 \mathrm{~mm} \text { glass plate }\end{array}$ \\
\hline Rated output per module * & $1.2 \mathrm{~W}$ \\
\hline Cell type & $\begin{array}{l}\text { mono-crystalline silicon (Sphelar }{ }^{\circledR} ; \text { Sphelar Power } \\
\text { Corp., Kyoto, Japan) }\end{array}$ \\
\hline Cell diameter & $1.2 \mathrm{~mm}$ \\
\hline Number of cells per module & 13,764 \\
\hline $\begin{array}{l}\text { Cell density in the semi-transparent zone } \\
\qquad(154 \mathrm{~mm} \times 158 \mathrm{~mm})\end{array}$ & 18.9 cell $\mathrm{cm}^{-2}$ \\
\hline $\begin{array}{l}\text { Front view occupation }(\%) \text { of the opaque materials in } \\
\text { the semi-transparent zone }\end{array}$ & $31 \%$ including the cells and the conductors \\
\hline Number of PV modules per blind & 3 \\
\hline
\end{tabular}




\subsection{Sunlight to Electricity Conversion Characteristics of the PV Blind}

The sunlight to electricity conversion characteristics of the PV blind were measured at a field plot on the Shimane University campus $\left(35^{\circ} 29^{\prime} \mathrm{N}, 133^{\circ} 04^{\prime} \mathrm{E}\right)$ on 10 October 2017; a sunny day. This experiment was designed to evaluate basic characteristics of the PV blind irradiated with natural sunlight without obstructions such as greenhouse glazing. The PV modules were supported $2 \mathrm{~m}$ above the ground (Figure 2). The PV module inclination was fixed at $26.5^{\circ}$, corresponding to the common slope of a conventional greenhouse glazing roof of this region. The azimuth of the PV-module normal was directed to true south. $I_{\mathrm{PVT}}$ and $I_{\mathrm{PVB}}$ were measured using pyranometers $\mathrm{P}_{\mathrm{PVT}}$ and $\mathrm{P}_{\mathrm{PVB}}$ (Figure 1b). Another pyranometer (ML-01) was positioned horizontally $2 \mathrm{~m}$ above the ground on the frame to measure the horizontal global irradiance $I_{\mathrm{H}}$. The current $i_{\mathrm{PV}}-$ voltage $V_{\mathrm{PV}}$ characteristics of the PV blind were measured using a voltage and current source/meter (6241A; ADC Corp., Tokyo, Japan) and a data acquisition unit (34970A; Agilent Technologies Inc., Santa Clara, CA, USA) at 1 min intervals. The accuracies of the voltage and current source/meter were $\pm 0.02 \%$ for voltage and $\pm 0.05 \%$ for current. The accuracy of the data acquisition unit was $\pm 0.005 \%$ for DC voltage measurements. The module efficiency $\eta_{\mathrm{M}}$ was determined by the percentage of the PV modules' power output $P_{\mathrm{PV}}$ to the impinging irradiance $I_{\mathrm{PVT}}+I_{\mathrm{PVB}}$ on the area $S_{\mathrm{PV}}$ of $500 \mathrm{~mm} \times 200 \mathrm{~mm} \times 3$ modules as

$$
\eta_{\mathrm{M}}=\frac{P_{\mathrm{PV}}}{\left(I_{\mathrm{PVT}}+I_{\mathrm{PVB}}\right) S_{\mathrm{PV}}} \times 100 \% .
$$

The angle $\gamma$ between direct beam sunlight irradiating on the PV module and the PV-module normal (Figure 1b) was calculated at $1 \mathrm{~min}$ intervals for the experimental date and site using the following geometric formula [58].

$$
\cos \gamma=\sin h \cos \varphi+\cos h \sin \varphi \cos (|\alpha-\beta|),
$$

where $h, \varphi, \alpha$, and $\beta$ represent the solar altitude, the PV module inclination, the azimuth of the sun, and the azimuth of the PV module normal, respectively.

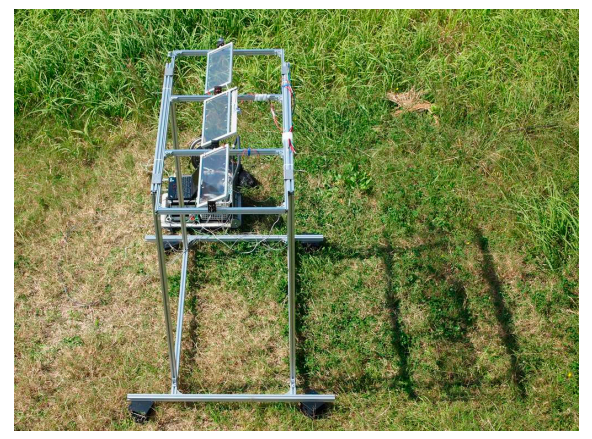

Figure 2. Electrical characteristics of the PV blind system consisting of the three PV modules were measured at a field plot on the Shimane University campus $\left(35^{\circ} 29^{\prime} \mathrm{N}, 133^{\circ} 04^{\prime}\right.$ E) on 10 October 2017.

\subsection{PV-Blind Control Circuit}

A motor drive circuit (Figure 3) was developed to turn the PV blind according to irradiance level. A pyranometer $P_{\text {SIGNAL }}$ (ML-01) transformed $I_{\mathrm{H}}$ into voltage as the input signal of the control circuit. An operational amplifier (LM358; Texas Instruments Inc., Dallas, TX, USA) linearly amplified the $P_{\text {SIGNAL }}$ output voltage. The amplification factor was regulated by an $R_{0}$ value of a variable resistor (Figure 3). The output voltage of the operational amplifier drove a transistor to control voltage $V_{\mathrm{CW}}$ and $V_{\mathrm{CCW}}$ at the $\mathrm{IN}_{1}$ and $\mathrm{IN}_{2}$ terminals of a DC motor full bridge driver (TB6643KQ; Toshiba Corp., Tokyo, Japan). The motor rotation direction was reversed according to the balance of $V_{\mathrm{CW}}$ and $V_{\mathrm{CCW}}$ [55]. The PV blind rotation from the perpendicular $\left(\theta=90^{\circ}\right.$, Figure $\left.4 \mathrm{~b}\right)$ to the parallel $\left(\theta=0^{\circ}\right.$, Figure $\left.4 \mathrm{a}\right)$ angle relative to a greenhouse roof surface was defined as clockwise $(\mathrm{CW})$. The reverse rotation was 
denoted as counter-clockwise (CCW). The $R_{0}$ value set a threshold $I_{\mathrm{H}}$ value for the blind rotation. The relation between the control voltage and the blind angle is

$$
\left\{\begin{array}{c}
\theta=0^{\circ}, V_{\mathrm{CW}}>V_{\mathrm{CCW}} \\
\theta=90^{\circ}, V_{\mathrm{CW}}<V_{\mathrm{CCW}}
\end{array}\right.
$$

The motor control circuit, a battery with 50 Ah rated capacity (JC50-12; Denryo Co. Ltd., Tokyo, Japan), and the PV module output terminals were connected to a charge-discharge controller (SA-MN05-8; Denryo Co. Ltd., Tokyo, Japan) to integrate the stand-alone power system (Figures $1 \mathrm{~b}$ and 3 ).

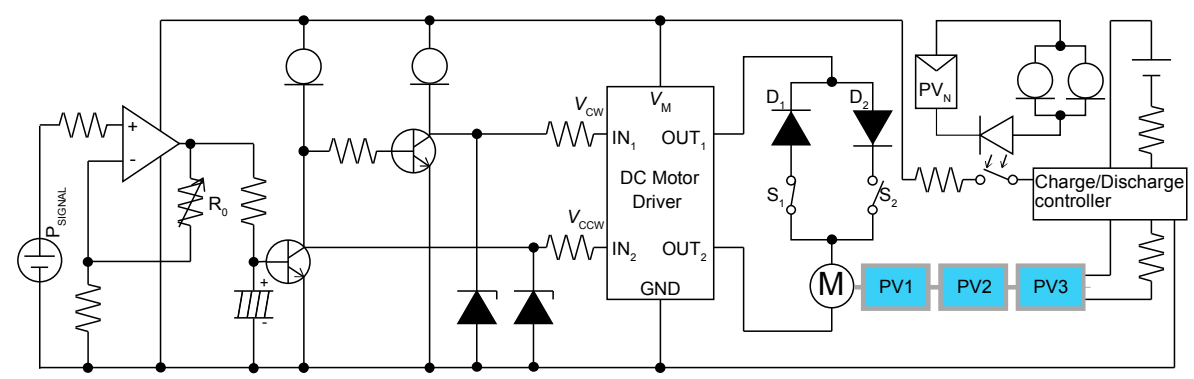

Figure 3. $\mathrm{PV}$ blind $\left(\mathrm{PV}_{1}-\mathrm{PV}_{3}\right)$ control circuit: $\mathrm{P}_{\mathrm{SIGNAL}}$ transforms the horizontal global irradiance into voltage. A variable resistor $\mathrm{R}_{0}$ sets a threshold irradiance level for blind rotations. An additional PV module $\left(\mathrm{PV}_{\mathrm{N}}\right)$ supplied current to a MOS FET relay to turn on the gate at dawn and to turn off the gate at dusk, in order to eliminate standby energy consumption at the motor drive circuit during night-time [55].

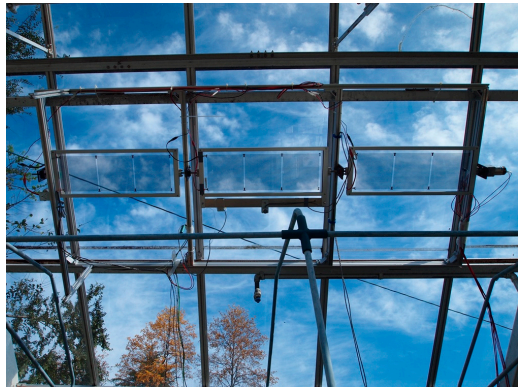

(a)

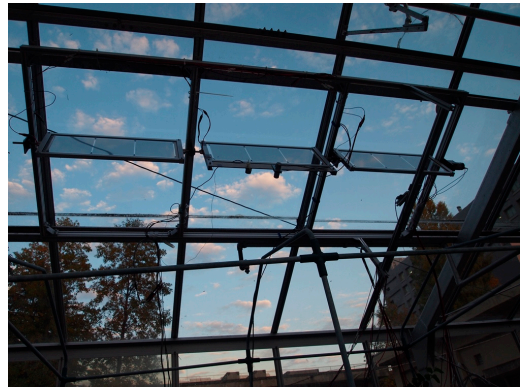

(b)

Figure 4. Semi-transparent PV blind installed underneath the greenhouse glass roof facing the eastern sky: the PV blind inclined at parallel $\left((\mathbf{a}), \theta=0^{\circ}\right)$ or perpendicular $\left((\mathbf{b}), \theta=90^{\circ}\right)$ to the roof surface. Supplemental Video S1 is available to see the PV blind operations on 2 March 2018.

\subsection{Verification of the PV Blind Characteristics at the Test Greenhouse}

The PV blind was installed underneath the $26.5^{\circ}$-sloped east-sky-facing roof of a north-south oriented greenhouse $(5.65 \mathrm{~m} \times 4.25 \mathrm{~m})$ at the Shimane University campus (Figure 5). The PV blind was installed underneath the roof because the prototype system was not water resistant. In the greenhouse, no crops were cultivated on the concrete floor. Pyranometer $P_{H}$ (ML-01) was used for measuring exterior horizontal global irradiance $I_{\mathrm{H}}$. Pyranometer $\mathrm{P}_{\mathrm{T}}(\mathrm{ML}-01)$ measured global irradiance on the inclined greenhouse roof surface $I_{\mathrm{T}}$ (facing $6^{\circ}$ to the north from the true east with $26.5^{\circ}$ inclination). Pyranometers $\mathrm{P}_{\mathrm{H}}, \mathrm{P}_{\mathrm{T}}$, and $\mathrm{P}_{\text {SIGNAL }}$ were positioned on the greenhouse ridge at $3.5 \mathrm{~m}$ height.

Electrical power generation characteristics of the PV blind inclined at $\theta=0^{\circ}$ (Figure 4a) were measured at 1 min intervals from 10:00 to 12:30 on 1 November 2017 using a data acquisition unit (34972A; Keysight Technologies Inc., Santa Rosa, CA, USA) and the voltage and current source/meter (6241A). The accuracy of the data acquisition unit was $\pm 0.005 \%$ for DC voltage measurements. 
Shading characteristics of the PV blind inclined at $\theta=0^{\circ}$ were measured at 1 min intervals on 6 November 2017 using pyranometers $\mathrm{P}_{\mathrm{T}}, \mathrm{P}_{\mathrm{PVT}}$, and $\mathrm{P}_{\text {Cell }}$, the output terminals of which were connected with the data acquisition unit (34972A). The sunlight transmittance of the greenhouse glazing was determined as $I_{\mathrm{PVT}}$ divided by $I_{\mathrm{T}}$. The sunlight transmittance of the PV module was determined as $I_{\text {Cell }}$ divided by $I_{\text {PVT }}$.

Then, the PV blind was connected to the control circuit (Figure 3). The values of $I_{\mathrm{H}}$, motor current $i_{\mathrm{M}}$, and motor voltage $V_{\mathrm{M}}$ were measured on 27 November 2017 at $10 \mathrm{~ms}$ intervals using a data-logger (HIOKI8430; Hioki E. E. Corp., Nagano, Japan) to determine the instantaneous electrical energy consumption during motor rotations. The accuracy of the data-logger was $\pm 0.1 \%$ for DC voltage and $\pm 0.01 \%$ for time. The target threshold $I_{\mathrm{H}}$ values for triggering the PV module rotations were set at 370,400 , and $440 \mathrm{~W} \mathrm{~m}^{-2}$, respectively, achieved by changing the $R_{0}$ values to 661,597 , and $534 \Omega$, respectively.

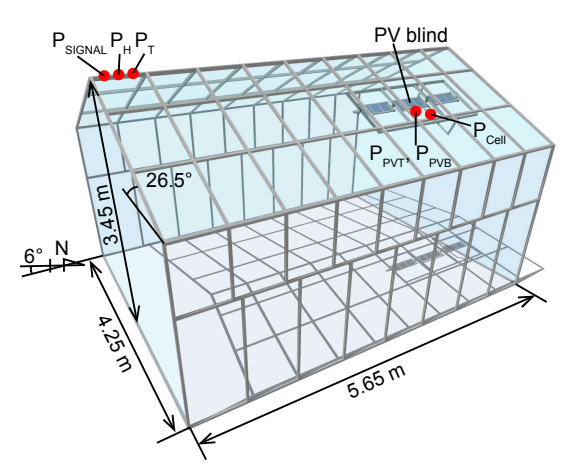

Figure 5. The PV blind installed underneath the greenhouse glass roof facing the eastern sky.

\subsection{Energy Balance of PV Blind System Operations}

The energy balance of the PV blind system installed underneath the greenhouse roof (Figure 5) was measured from 8 December 2017 through 25 April 2018. The threshold $I_{\mathrm{H}}$ value for PV blind rotations was set at $500 \mathrm{~W} \mathrm{~m}^{-2}$ to turn the PV blind actively during winter-spring. The PV-generated current $i_{\mathrm{PV}}$, the charging current into the battery $i_{\mathrm{C}}$, the control current to the motor drive circuit $i_{\mathrm{D}}, I_{\mathrm{H}}$, $I_{\mathrm{T}}, I_{\mathrm{PVT}}, I_{\mathrm{PVB}}$, and voltages at the PV module, the battery, and the circuit terminals were measured at $10 \mathrm{~s}$ intervals using the data acquisition unit (34972A). By integrating the product of the voltage and current with the duration, the cumulative energy generated by the PV module $E_{\mathrm{PV}}$, charged into the battery $E_{\mathrm{C}}$, and supplied to the motor drive circuit $E_{\mathrm{D}}$, was calculated. Subsequently, total cumulative energy consumption $E_{\mathrm{i}}$ of the charge/discharge controller, conducting wires, shunt resistances, and the internal resistance of the battery (i.e., internal system energy-dissipation) were calculated using the following formula:

$$
E_{\mathrm{i}}=E_{\mathrm{PV}}-E_{\mathrm{D}}-E_{\mathrm{C}} .
$$

As described in the Results section, the energy generated by the PV blind exceeded the demand of the PV-blind system operations. Consequently, the battery voltage approached the upper limit $(13 \mathrm{~V})$ of the charging cutoff in mid-February 2018. Accordingly, discharge of energy stored in the battery to some loads was demanded. For this reason, on 14 February 2018, light-emitting diodes (LEDs, HLMP-1540; Broadcom Ltd., San Jose, CA, USA) were connected additionally in parallel to the load terminal of the charge-discharge controller (SA-MN05-8) as a model greenhouse load. The electrical power consumption of the additional LED load with current regulating diodes was $0.4 \mathrm{~W}$. It was operated $24 \mathrm{~h}$ per day. The cumulative energy consumed at the additional LED load $E_{\mathrm{L}}$ had been incorporated into Equation (4) since the LED load was added. Therefore, the energy balance equation became 


$$
E_{\mathrm{PV}}=E_{\mathrm{D}}+E_{\mathrm{i}}+E_{\mathrm{C}}+E_{\mathrm{L}}
$$

The last terms $\left(E_{\mathrm{C}}+E_{\mathrm{L}}\right)$ represent the surplus of electrical energy generated by the PV blind. On 14 February, all measurements were suspended to add the LED load.

\section{Results}

\subsection{Sunlight to Electricity Conversion Characteristics of the PV Blind}

The sunlight to electricity conversion characteristics of the PV blind under natural sunlight were measured in a field plot on the Shimane University campus on 10 October 2017; a sunny day. $I_{\mathrm{H}}$, $I_{\mathrm{PVT}}$, and $I_{\mathrm{PVB}}$ are depicted in Figure $6 \mathrm{a}$. The PV blind received approximately $85 \%$ of the total irradiance from the sky and $15 \%$ from ground-reflected radiation. The power $P_{\mathrm{PV}}$-voltage $V_{\mathrm{PV}}$ curves of the PV blind are depicted in Figure $6 \mathrm{~b}$. The peak values of each $P_{\mathrm{PV}}$ curve were defined as $P_{\max }$. The maximum $P_{\max }$ value of the day was $3.75 \mathrm{~W}\left(V_{\mathrm{PV}}=14.9 \mathrm{~V}, i_{\mathrm{PV}}=251 \mathrm{~mA}\right)$ at $11: 59$ when the total incident irradiance $I_{\mathrm{PVB}}+I_{\mathrm{PVB}}=1113 \mathrm{~W} \mathrm{~m}^{-2}$ (Figure 6c). The $P_{\max }$ value of $3.75 \mathrm{~W}$ corresponds to $12.5 \mathrm{~W} \mathrm{~m}^{-2}$. The $P_{\max }$ values generally followed the course of bifacial incident irradiance $I_{\mathrm{PVT}}+I_{\mathrm{PVB}}$ (Figure 6c). The PV module efficiency $\eta_{M}$ was determined by Formula (1) (Figure 6c). The average $\eta_{M}$ during 9:02-16:00 was 1.2\% over a wide incident angle $\gamma$ of direct sunlight (Figure 7a,b).

On 1 November 2017, the PV blind was installed underneath the eastern roof glazing of the north-south oriented greenhouse. The PV modules faced the eastern sky with $26.5^{\circ}$ inclination parallel to the greenhouse roof. Irradiance and $P_{\mathrm{PV}}-V_{\mathrm{PV}}$ characteristics of the $\mathrm{PV}$ blind are depicted in Figure 6d,e. The PV modules were irradiated with direct sunlight from 10:00 to 12:30 through the greenhouse glazing. For other hours, the PV modules were frequently shaded by the greenhouse frame structures. The maximum $P_{\max }$ value of the day was $2.04 \mathrm{~W}\left(V_{\mathrm{PV}}=14.6 \mathrm{~V}, i_{\mathrm{PV}}=139 \mathrm{~mA}\right)$ at 10:00 when incident irradiance $I_{\mathrm{PVB}}+I_{\mathrm{PVB}}=583 \mathrm{~W} \mathrm{~m}^{-2}$ (Figure $6 \mathrm{f}$ ). The $P_{\max }$ value of $2.04 \mathrm{~W}$ corresponds to $6.8 \mathrm{~W} \mathrm{~m}^{-2}$. The average $\eta_{\mathrm{M}}$ during 10:00-12:30 was $1.0 \%$ (Figure $6 \mathrm{f}$ ). The loss of $\eta_{\mathrm{M}}$ under the greenhouse roof was attributable to the partial shadow of the greenhouse narrow frames on part of the PV module area.

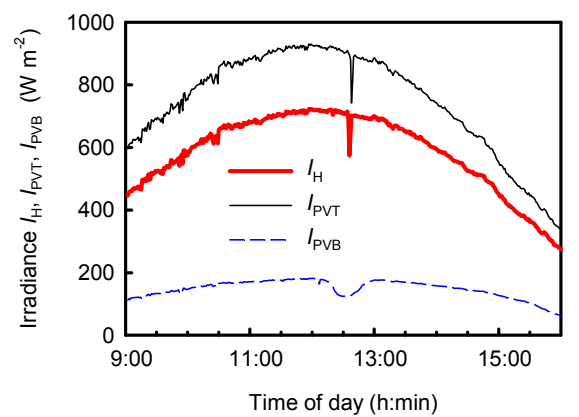

(a)

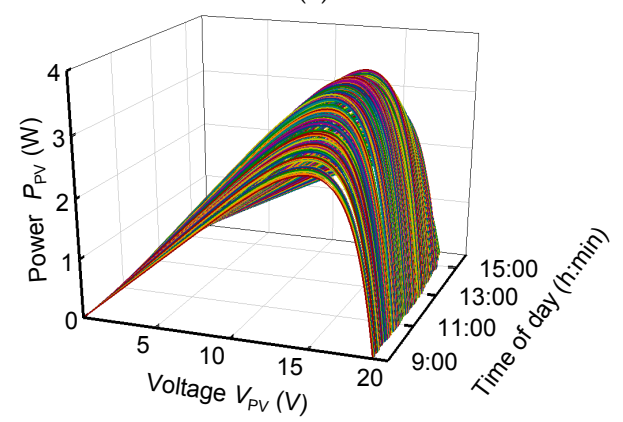

(b)

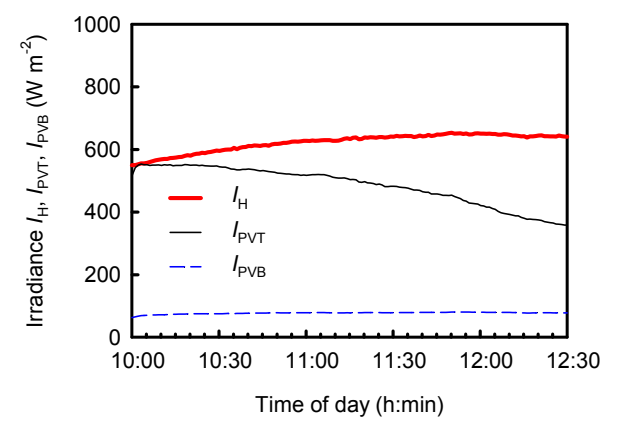

(d)

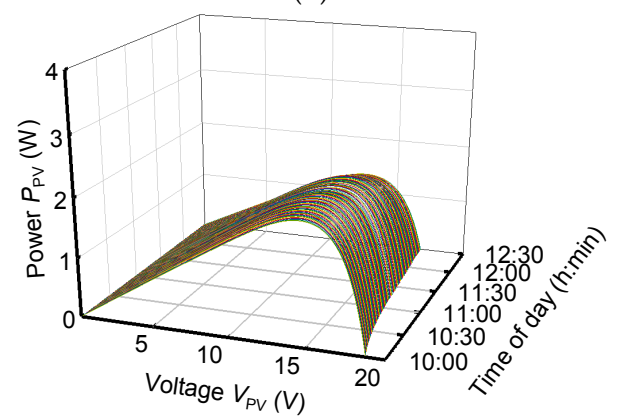

(e)

Figure 6. Cont. 


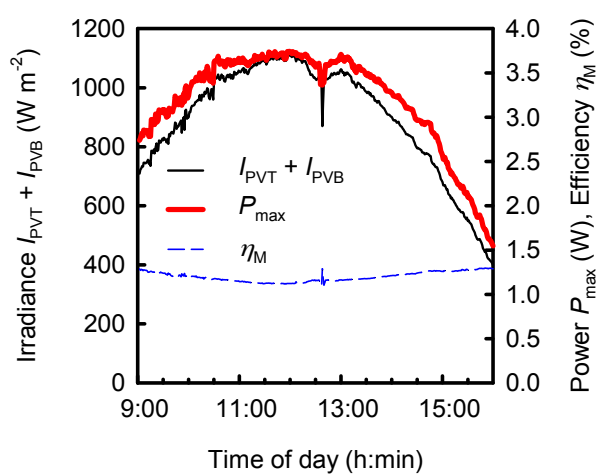

(c)

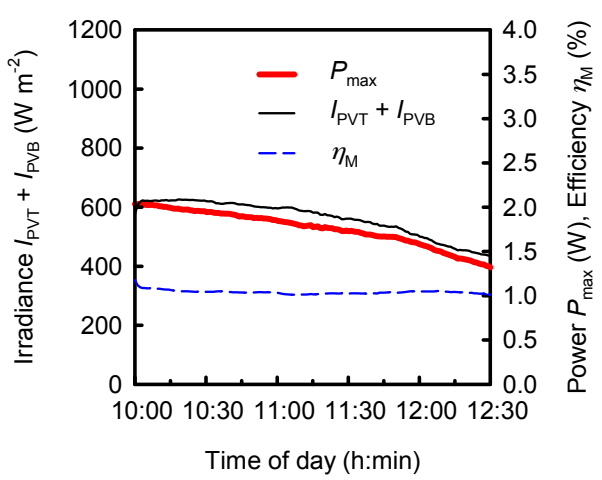

(f)

Figure 6. Electrical characteristics of the PV blind measured at the grass plot $(\mathbf{a}-\mathbf{c})$ or underneath the greenhouse roof $(\mathbf{d}-\mathbf{f})$ : $(\mathbf{a}, \mathbf{d})$ horizontal global irradiance $I_{\mathrm{H}}$, global irradiance on the inclined top surface $I_{\mathrm{PVT}}$, and bottom surface $I_{\mathrm{PVB}} ;(\mathbf{b}, \mathbf{e})$ power-voltage characteristics of the PV blind; $(\mathbf{c}, \mathbf{f})$ bifacial incident irradiance $I_{\mathrm{PVT}}+I_{\mathrm{PVB}}$, peak power $P_{\max }$, and module efficiency $\eta_{\mathrm{M}}$.

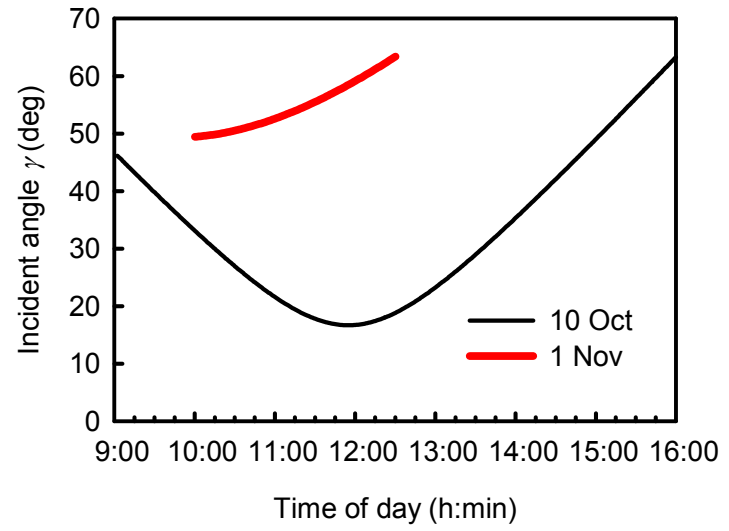

(a)

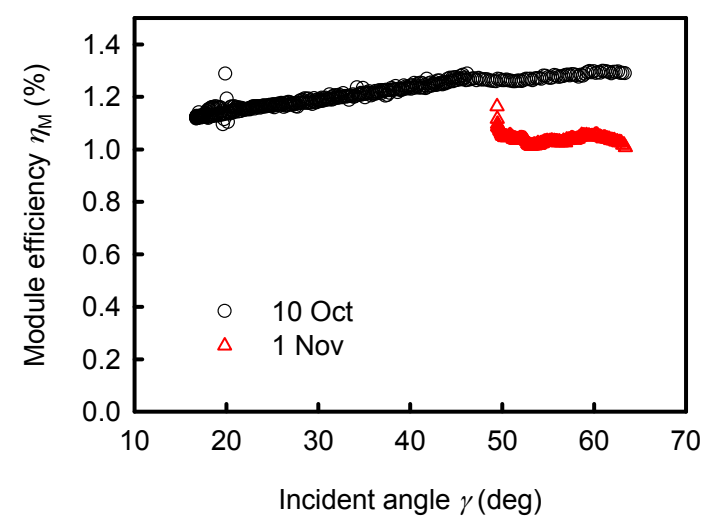

(b)

Figure 7. Module efficiency $\eta_{\mathrm{M}}$ with respect to the incident angle $\gamma$ of direct sunlight: (a) angle $\gamma$ on 10 October at the field plot and on 1 November in the greenhouse; (b) $\eta_{\mathrm{M}}$ with respect to $\gamma$.

\subsection{Sunlight Transmittance of the PV Blind}

The sunlight transmittance of the PV blind and the greenhouse glazing was measured on 6 November 2017. The PV blind was positioned underneath the eastern roof glazing of the greenhouse (Figure 5). The PV blind was irradiated with direct beam sunlight through the greenhouse glazing from 10:00 to 12:30. Graphs of $I_{\mathrm{T}}, I_{\mathrm{PVT}}$, and $I_{\text {Cell }}$ are portrayed in Figure $8 \mathrm{a}$. $I_{\mathrm{T}}$ peaked at 10:14. $I_{\mathrm{PVT}}$ generally followed the course of $I_{\mathrm{T}}$ with constantly attenuated values according to the partial sunlight scattering at the greenhouse glazing. However, around 10:25, $I_{\mathrm{PVT}}$ decreased sharply because only pyranometer $\mathrm{P}_{\text {PVT }}$ was shaded by a narrow greenhouse frame. $\mathrm{P}_{\text {Cell }}$ was in the shadow of the semi-transparent area (154 mm $\times 158 \mathrm{~mm}$ square, as depicted in Figure 1a) of the PV module from 10:01 to 11:17. Direct beam sunlight reached $\mathrm{P}_{\mathrm{Cell}}$ from outside of the PV module during other hours. The sunlight transmittance of the greenhouse roof glass was ascertained as $I_{\mathrm{PVT}}$ over $I_{\mathrm{T}}$ when $P_{\mathrm{PVT}}$ was not shaded by any opaque obstruction during 10:34-11:17. The sunlight transmittance of the PV module was determined by $I_{\text {Cell }}$ over $I_{\mathrm{PVT}}$ during 10:34-11:17. During the period, $\gamma$ was $52-55^{\circ}$ (Figure $8 \mathrm{~b}$ ). The average sunlight transmittances of the greenhouse glass roof and the PV module were $85 \%$ and $60 \%$, respectively (Figure $8 \mathrm{c}$ ). The average value of the total transmittance of the overlapping greenhouse glazing and the PV module was 51\% (Figure 8c). 


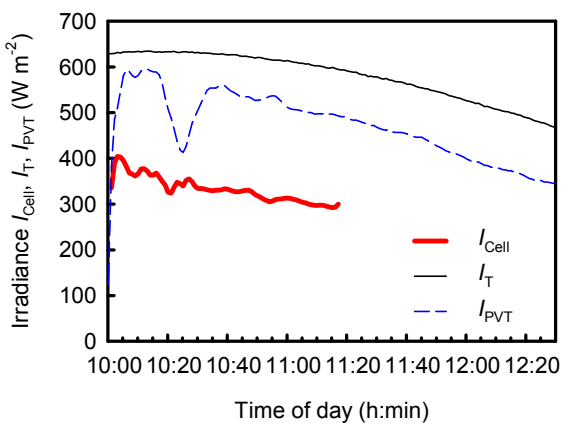

(a)

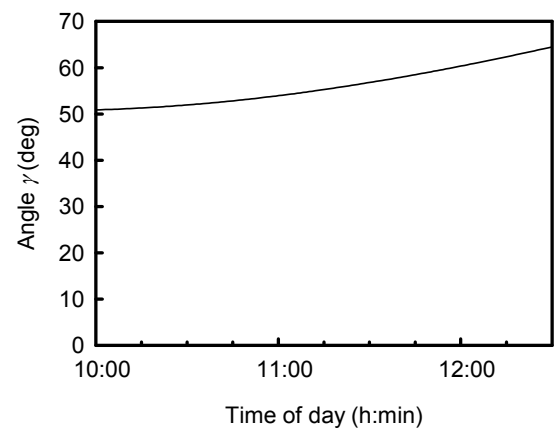

(b)

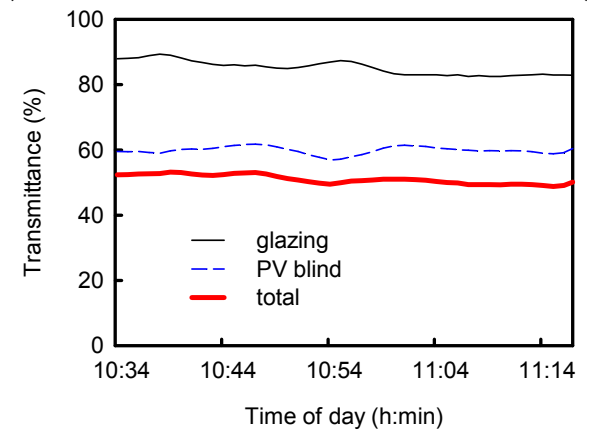

(c)

Figure 8. Sunlight transmission of the PV blind and the greenhouse glazing: (a) $I_{\text {Cell }}$ was depicted during 10:01-11:17 when the direct sunlight reached to $P_{\text {Cell }}$ through the $154 \mathrm{~mm} \times 158 \mathrm{~mm}$ semi-transparent area of the PV module; (b) the direct beam irradiance impinged the PV blind from angle $\gamma ;$ (c) transmittances of glazing, the PV blind, and the total of the glazing and the PV blind.

\subsection{Observations of the PV Blind Rotations in Response to Irradiance}

The PV blind operations were tested on 27 November 2017. The PV blind, connected with the control circuit (Figure 3), was positioned underneath the eastern glazing roof of the test greenhouse (Figure 5). The PV blind turned automatically in response to $I_{\mathrm{H}}$. The desired threshold $I_{\mathrm{H}}$ value for the CW or CCW rotation of the PV blind was achieved by implementing the proper $R_{0}$ value. Table 2 presents the threshold $I_{\mathrm{H}}$ of the $\mathrm{CW}$ or CCW rotations at three $R_{0}$ values. The motor drive-circuit operations are described herein using data obtained at $R_{0}=597 \Omega$. When $I_{\mathrm{H}}$ was $402 \mathrm{~W} \mathrm{~m}^{-2}$ at 10:26:35 $\left(\mathrm{CW}_{2}\right)$ and 10:28:25 $\left(\mathrm{CW}_{3}\right)$ and $401 \mathrm{~W} \mathrm{~m}^{-2}$ at 10:28:54 $\left(\mathrm{CW}_{4}\right)$, the PV blind was rotated $\mathrm{CW}$ (Figure 9a). The PV blind was rotated CCW when $I_{\mathrm{H}}$ was $397 \mathrm{~W} \mathrm{~m}^{-2}$ at 10:27:47 $\left(\mathrm{CCW}_{2}\right)$ and at 10:28:48 $\left(\mathrm{CCW}_{3}\right)$ and $399 \mathrm{~W} \mathrm{~m}^{-2}$ at 10:28:58 $\left(\mathrm{CCW}_{4}\right)$. Motor current $i_{\mathrm{M}}$, voltage $V_{\mathrm{M}}$, and operating power $\left(P_{\mathrm{M}}=i_{\mathrm{M}} \times V_{\mathrm{M}}\right)$ during the motor rotations are presented in Figure $9 \mathrm{~b}\left(\mathrm{CW}_{2}\right)$ and in Figure $9 \mathrm{c}$ $\left(\mathrm{CCW}_{2}\right)$. The negative values of voltage and current represent the CCW rotation. Instantaneous $P_{\mathrm{M}}$ peaked at the beginning of the rotations and subsequently converged to $3 \mathrm{~W}$. Rotation duration $t$ and energy consumption $e$ of the DC motor during the CW and CCW rotations are presented in Table 2. The respective energy consumption values of the single $\mathrm{CW}$ and CCW rotations were 11.1-14.5 J and 9.9-14.1 J. 


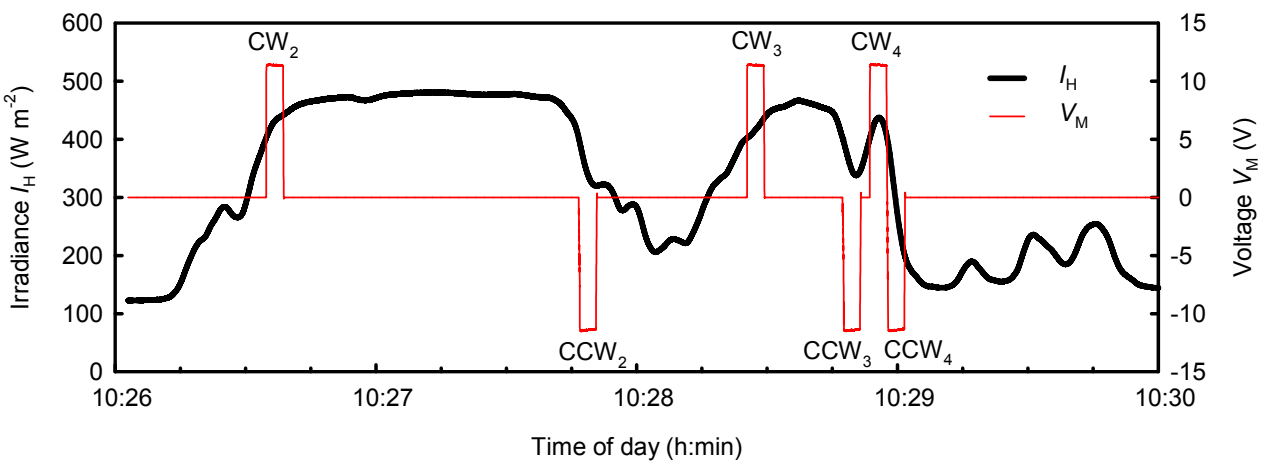

(a)

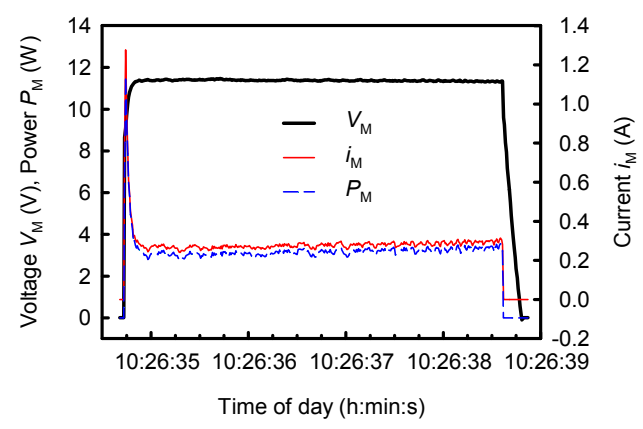

(b)

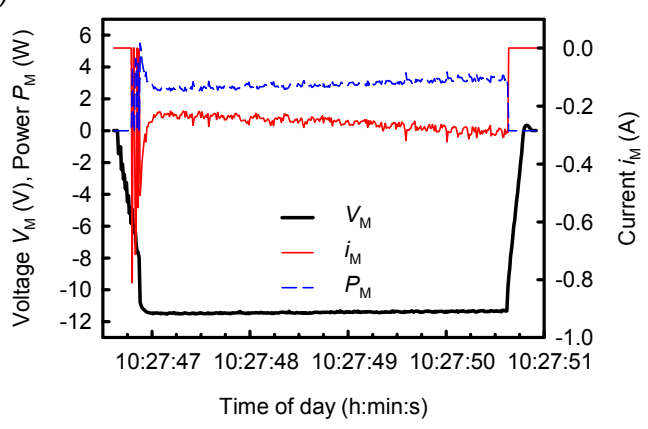

(c)

Figure 9. PV blind operations in response to irradiance $I_{\mathrm{H}}$ on 27 November 2017: (a) motor voltage $V_{\mathrm{M}}$ represents the blind operations at threshold $I_{\mathrm{H}}=400 \mathrm{~W} \mathrm{~m}^{-2} ;(\mathbf{b})$ motor current $i_{\mathrm{M}}$, voltage $V_{\mathrm{M}}$, and power $P_{\mathrm{M}}$ during $\mathrm{CW}_{2} ;$ (c) $\mathrm{CCW}_{2}$.

Table 2. Threshold irradiance $I_{\mathrm{H}}$, rotating duration $t$ of the direct current (DC) motor, and energy consumption $e$ during the clockwise $(\mathrm{CW})$ and counter-clockwise $(\mathrm{CCW})$ rotations at each $R_{0}$ value of the PV blind control circuit.

\begin{tabular}{|c|c|c|c|c|c|}
\hline$R_{0}(\Omega)$ & $\begin{array}{l}\text { CW/CCW } \\
\text { Rotation }\end{array}$ & $\begin{array}{l}\text { Blind Rotation } \\
\text { Start Time * }\end{array}$ & $\begin{array}{l}\text { Threshold } I_{H} \\
\quad\left(\mathrm{~W} \mathrm{~m}^{-2}\right)\end{array}$ & $\begin{array}{c}\text { Rotation } \\
\text { Duration } t(\mathrm{~s})\end{array}$ & Energy $e(\mathrm{~J})$ \\
\hline \multirow{2}{*}{661} & $\mathrm{CW}_{1}$ & 10:09:19 & 369 & 4.0 & 14.5 \\
\hline & $\mathrm{CCW}_{1}$ & 10:17:37 & 362 & 4.2 & 14.1 \\
\hline \multirow{6}{*}{597} & $\mathrm{CW}_{2}$ & $10: 26: 35$ & 402 & 3.9 & 12.6 \\
\hline & $\mathrm{CCW}_{2}$ & $10: 27: 47$ & 397 & 3.8 & 11.3 \\
\hline & $\mathrm{CW}_{3}$ & $10: 28: 25$ & 402 & 3.9 & 12.6 \\
\hline & $\mathrm{CCW}_{3}$ & $10: 28: 48$ & 397 & 3.8 & 11.3 \\
\hline & $\mathrm{CW}_{4}$ & $10: 28: 54$ & 401 & 3.9 & 12.4 \\
\hline & $\mathrm{CCW}_{4}$ & 10:28:58 & 399 & 3.8 & 11.1 \\
\hline \multirow{2}{*}{534} & $\mathrm{CCW}_{5}$ & 11:06:02 & 438 & 3.7 & 9.9 \\
\hline & $\mathrm{CW}_{5}$ & 11:08:06 & 444 & 3.7 & 11.1 \\
\hline
\end{tabular}

${ }^{*}$ Measured on 27 November 2017.

\subsection{Energy Balance of the PV Blind System}

The PV blind was operated without outage for five months from 8 December 2017 through 25 April 2018 (Figure 10), although the PV blind and measurement systems were suspended during LED load installation on 14 February. The $I_{\mathrm{H}}$ values in winter were generally low at the greenhouse location because of actual cloudy sky conditions and sunlight shading by university buildings during the low solar altitude season. For example, on 15 December, the $I_{\mathrm{H}}$ curve was suppressed in the morning and afternoon by the building shade, although the sky was fair throughout the day. After mid-March, the $I_{\mathrm{H}}$ curve became smooth on sunny days as the sun path became higher than the buildings. The PV 
blind was rotated 2255 times in the CW direction and 2255 times in the CCW direction during five months. On heavy cloudy days, the blind did not rotate. It retained $\theta=90^{\circ}$, prioritizing sunlight intake into the greenhouse. On sunny days, $P_{\mathrm{PV}}$ reached $2 \mathrm{~W}$ in December, $3 \mathrm{~W}$ in January and February, and $4 \mathrm{~W}$ in March and April; $P_{\mathrm{PV}}$ was less than $0.5 \mathrm{~W}$ on heavy cloudy days. The daily total system efficiency $\eta_{0}$ was calculated using Formula (6) according to the surplus energy of PV blind operations against the daily sunlight energy received by the horizontal occupation of the PV blind.

$$
\eta_{0}=\frac{\int_{0 \mathrm{~h}}^{24 \mathrm{~h}}\left(P_{\mathrm{C}}+P_{\mathrm{L}}\right) \mathrm{d} t}{S_{\mathrm{PV}} \cos 26.5^{\circ} \int_{0 \mathrm{~h}}^{24 \mathrm{~h}} I_{\mathrm{H}} \mathrm{d} t} \times 100 \%,
$$

where $P_{\mathrm{C}}$ and $P_{\mathrm{L}}$ denote power input to the battery and power supplied to the load LEDs, respectively. $P_{\mathrm{L}}$ had been zero until the LED load was installed to the system on 14 February.

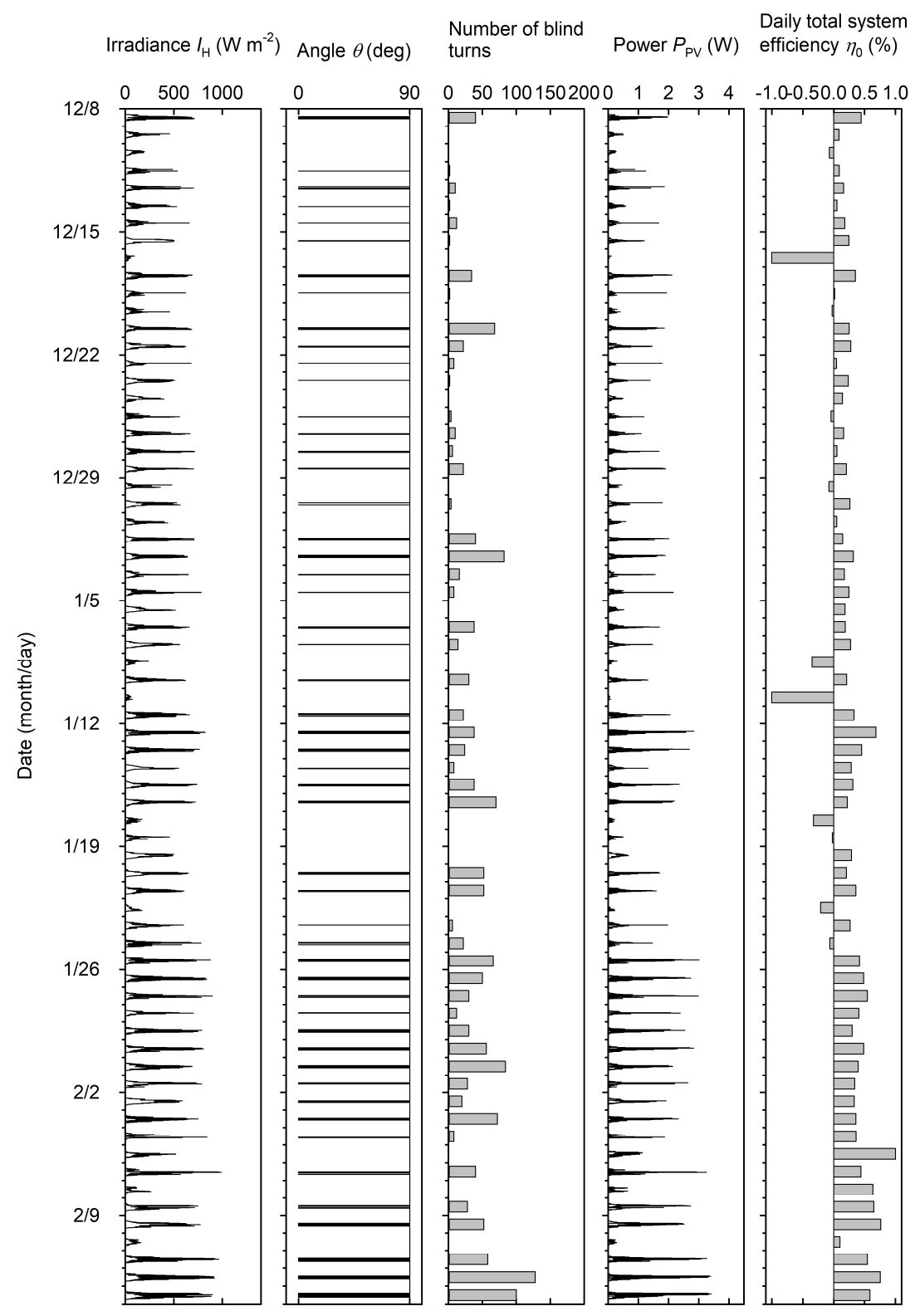

(a)

Figure 10. Cont. 


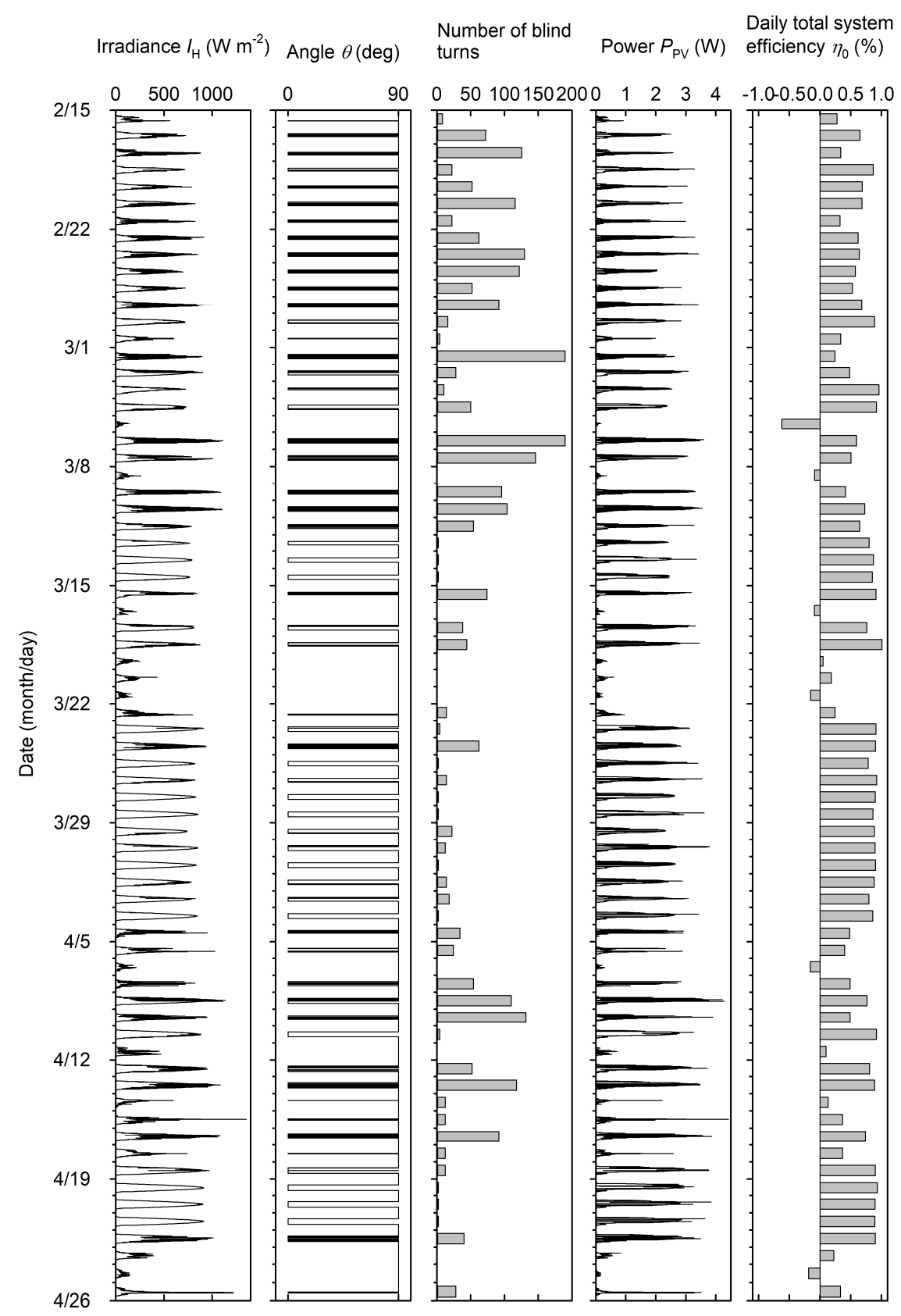

(b)

Figure 10. Verification of automatic operations of the PV blind system in winter (a) and in spring (b). On 14 February, blind system operations were suspended to install the additional light-emitting diode (LED) load to the system.

$\eta_{0}=0.68 \%$ was recorded on 12 January 2018 (Figure 10a). It was a partially cloudy day. $I_{\mathrm{H}}$ frequently exceeded $500 \mathrm{~W} \mathrm{~m}^{-2}$ during the day (Figure 11a). Thereby, the blind often turned to $\theta=0^{\circ}$. The PV blind generated electricity up to $3 \mathrm{~W}$. Sunny day data obtained on 19 April 2018 are presented in Figure $11 \mathrm{~b}$. They show that $P_{\mathrm{PV}}$ increased in the early morning because the PV blind faced the eastern sky. At 8:16, the PV blind turned to $\theta=0^{\circ}$ when $I_{\mathrm{H}}$ reached at $494 \mathrm{~W} \mathrm{~m}^{-2}$. At that moment, $P_{\mathrm{PV}}$ jumped up to $2.7 \mathrm{~W}$. The $P_{\mathrm{PV}}$ value was maintained as higher than $2 \mathrm{~W}$ until $P_{\mathrm{PV}}$ dropped at 13:47, when direct sunlight failed to shine on the PV blind because of the reflection at the western greenhouse roof. The PV blind turned to $\theta=90^{\circ}$ at $16: 00$ when $I_{\mathrm{H}}$ decreased to $460 \mathrm{~W} \mathrm{~m}^{-2} \cdot \eta_{0}=0.93 \%$ on 19 April. The lowest value of $\eta_{0}$ was recorded on 10 January when the greenhouse was covered 
with snow. $I_{\mathrm{H}}$ was less than $100 \mathrm{~W} \mathrm{~m}^{-2}$. Thereby, $P_{\mathrm{PV}}$ was nearly $0 \mathrm{~W}$. The blind system consumed stand-by operation energy that led to the least $\eta_{0}$ of $-1.00 \%$. The negative value means that the system maintenance energy was supplied by the battery. The mean and median values of $\eta_{0}$ were $0.22 \%$ and $0.25 \%$, respectively, during winter (8 December to 13 February). From mid-February to mid-March, irradiance sometimes approached $1 \mathrm{~kW} \mathrm{~m}^{-2}$ instantaneously, but the sky was covered with discrete clouds. Accordingly, the number of blind turns increased as the irradiance frequently changed, as it did on 1 and 6 March. As the solar elevation increased, the sun path was not blocked by university buildings, which led to more available insolation and greater $\eta_{0}$. From mid-March, the number of clear sky days increased. On cloudless days, blinds usually turned once in the morning to $\theta=0^{\circ}$ and once in the afternoon to $\theta=90^{\circ}$. Cloudless days $\eta_{0}$ were constantly $1 \%$. Mean and median values of $\eta_{0}$ were $0.58 \%$ and $0.68 \%$, respectively, during spring (15 February through 25 April).

The PV blind was parallel to the roof for only 2\% duration in the winter (Figure 12a). During the $2 \%$ duration, the PV blind generated $32 \%$ of the total electrical energy generated during the season (Figure 12b), indicating that the PV orientation parallel to the greenhouse roof is the best mode for electricity generation. The PV blind at the perpendicular angle to the roof produced $68 \%$ of electrical energy by virtue of the bifacial validity of the PV modules and isotropic susceptibility of the spherical PV cells. The duration at $\theta=0^{\circ}$ increased to $14 \%$ in spring (Figure 12c). Accordingly, $72 \%$ of electrical energy was produced when the blind was parallel to the roof (Figure 12d).

At the end of the operation test, $E_{\mathrm{PV}}, E_{\mathrm{C}}+E_{\mathrm{L}}, E_{\mathrm{D}}$, and $E_{\mathrm{i}}$ were $2659 \mathrm{~kJ}, 2125 \mathrm{~kJ}, 399 \mathrm{~kJ}$, and $135 \mathrm{~kJ}$, respectively (Figure 13 and Table 3). Table 2 indicated that a single rotation of the PV blind consumes up to $15 \mathrm{~J}$. The PV blind rotated 4510 times during the period. In all, $15 \times 4510=67.7 \mathrm{~kJ}$ was approximately consumed for the blind rotations. This value corresponded to $17 \%$ of $E_{\mathrm{D}} \cdot E_{\mathrm{i}}$ was $1.0 \mathrm{~kJ} \mathrm{day}{ }^{-1} \mathrm{almost}$ constantly (Table 3 ). Although the sky condition was generally overcast in winter, $E_{\mathrm{C}}$ was greater than $E_{\mathrm{D}}$. Along with the daily insolation increased in spring, $E_{\mathrm{PV}}$ increased gradually. Consequently, surplus energy $E_{\mathrm{C}}+E_{\mathrm{L}}$ also increased (Figure 13). Surplus electrical energy of $2125 \mathrm{~kJ}$ had been obtained by the end of the experiments.

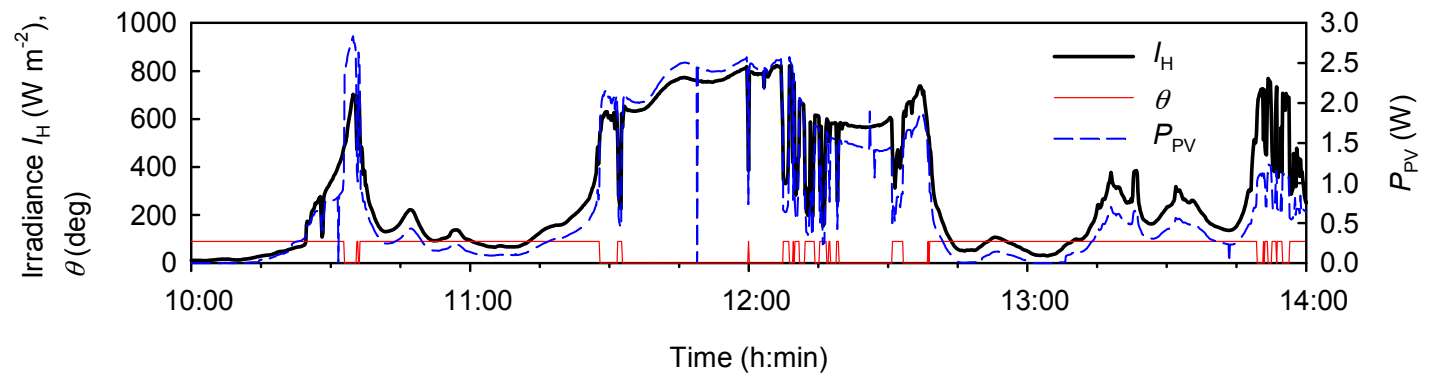

(a)

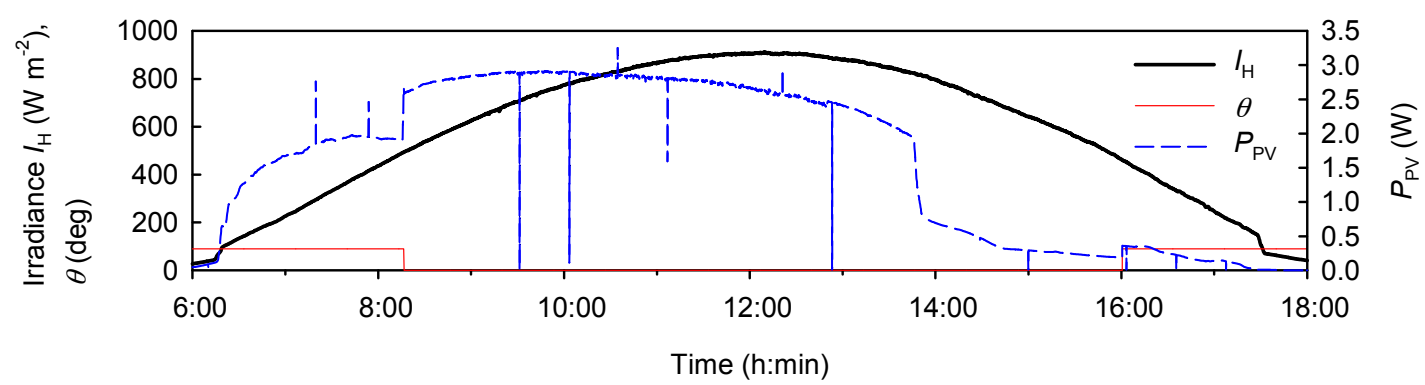

(b)

Figure 11. PV blind operations on 12 January (a) and 19 April (b). 


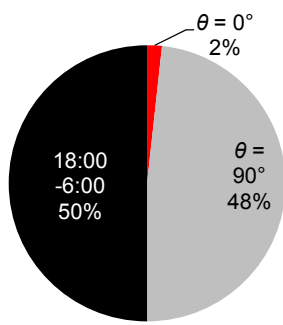

(a)

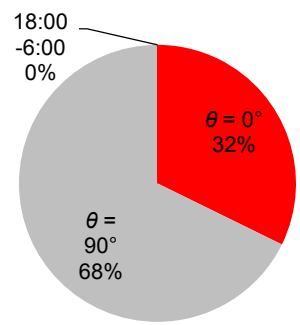

(b)

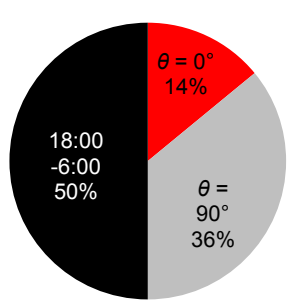

(c)

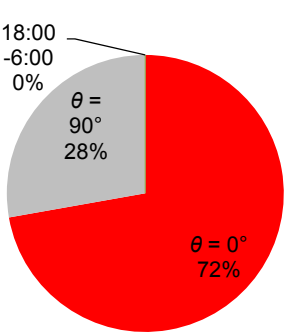

(d)

Figure 12. Duration percentage of night-time (18:00-6:00) and day time at $\theta=0^{\circ}$ and $90^{\circ}$ in winter ((a), 8 December to 13 February) and in spring ((c), 15 February to 25 April); the percentage of the PV-module generated energy during night-time and day time at $\theta=0^{\circ}$ and $90^{\circ}$ in winter $(\mathbf{b})$ and in spring (d).

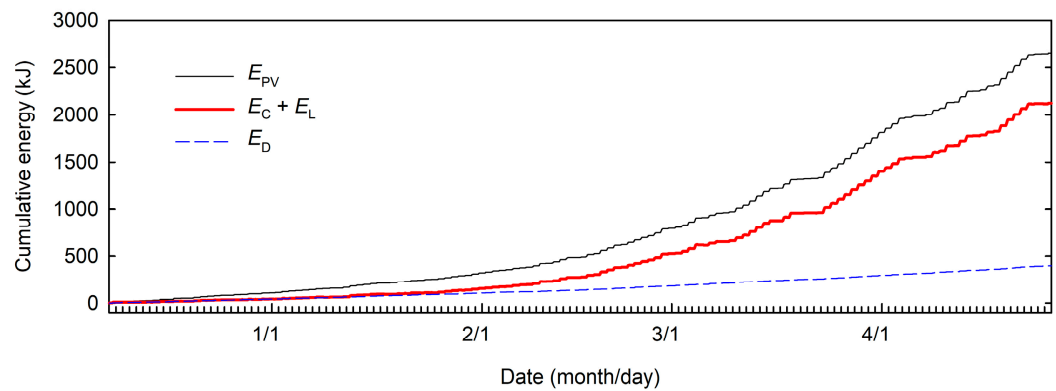

Figure 13. Energy balance of the PV blind system during the five-month operation test: $E_{\mathrm{PV}}, E_{\mathrm{C}}+E_{\mathrm{L}}$, and $E_{\mathrm{D}}$ represent the cumulative PV generated energy, surplus energy, and drive-circuit supplied energy, respectively.

Table 3. Energy balance of the PV blind system at the end of five-month operation test.

\begin{tabular}{ccccc}
\hline & $E_{\mathbf{P V}}$ & $E_{\mathbf{C}}+E_{\mathbf{L}} *$ & $E_{\mathbf{D}}$ & $E_{\mathbf{i}}$ \\
\hline $\mathbf{~ k J}$ & 2659.10 & 2125.26 & 398.80 & 135.04 \\
kJ day $^{-1}$ & 19.27 & 15.40 & 2.89 & 0.98 \\
$\mathbf{W h ~ m}^{-\mathbf{2}}$ day $^{-1}$ & 19.94 & 15.93 & 2.99 & 1.01
\end{tabular}

* $E_{\mathrm{L}}$ consists of 70-day data obtained since the light-emitting diode (LED) load was installed to the blind system.

\section{Discussion}

The PV system concurrently functioned as a blind to regulate the shading level in the greenhouse and as an electricity power generator. The PV blind system prioritized the sunlight intake in the greenhouse by virtue of its movability and semi-transparency, whereas conventional large-scale PV greenhouses with full [59-62] or half [63-68] roof area coverage prioritized electrical power generation. The prototype PV blind system operated successfully according to the threshold level of solar irradiance during winter-spring. The threshold level was regulated by changing the value of the variable resistor in the control circuit (Table 2). The blind operation was automatic and energetically stand-alone with $2125 \mathrm{~kJ}$ of surplus electrical energy at the end of the experiments.

The annual energy balance of the PV-blind system operation was estimated using experimental and local meteorological statistical data. Annual $I_{\mathrm{H}}$ was estimated based on local insolation data obtained during the prior nine years (2009-2017) [69]. Three levels of $\eta_{0}$ were assumed: $0.2 \%, 0.6 \%$, and $1.0 \%$. Assuming that replications of the present PV blind system cover the entire greenhouse roof underneath the glazing, the surplus electrical energy per unit greenhouse area was estimated annually (Figure 14). For $\eta_{0}=0.2 \%, 2.6 \mathrm{kWh} \mathrm{m}^{-2}$ year $^{-1}$ of greenhouse loads can be supplied. Yano et al. [70,71] 
demonstrated that a single-span plastic greenhouse equipped with a side ventilation controller demanded electrical energy of $0.1 \mathrm{kWh} \mathrm{m}^{-2}$ year $^{-1}$ for automatic window operations in response to the greenhouse interior temperature (Table 4). The present PV blind system would be sufficient to compensate such small-scale greenhouse demand for microclimate control. The actual surplus electrical energy obtained from the present experiments is also depicted in Figure 14. That is approximately on the line of $\eta_{0}=0.6 \%$ estimation. Another study estimated that $7 \mathrm{kWh} \mathrm{m}^{-2}$ year $^{-1}$ of electrical energy is demanded in a Spanish pepper greenhouse equipped with fans, irrigation and fertilization systems, fuel burners, window-operation motors, screen motors, climate control automatism, compressors, and fuel reservoirs [72]. In a Spanish greenhouse with window and pump operations, $3 \mathrm{kWh} \mathrm{m}^{-2}$ per eight months of electrical energy was demanded [29]. The surplus of electrical energy producible by the PV blind system underneath the roof glazing with $\eta_{0}=0.6 \%$ was estimated as compensating the electricity demand in such Mediterranean greenhouses. The total compensation of electricity demands is particularly valuable in rural areas where greenhouses are often far from power lines [73]. The $E_{\mathrm{C}}$ value of $13 \mathrm{kWh} \mathrm{m}^{-2}$ year ${ }^{-1}$ can be a surplus assuming that $\eta_{0}=1 \%$. Some additional greenhouse loads can be operated using this electrical energy. Campiotti et al. [74] reported that electrical power requirements range from $9 \mathrm{kWh} \mathrm{m}^{-2}$ year ${ }^{-1}$ for Mediterranean greenhouses with advanced climate control (heating, cooling or ventilation) to $2 \mathrm{kWh} \mathrm{m}^{-2}$ year $^{-1}$ for low-technology greenhouses (Table 4). Some other reports have described $20-30 \mathrm{kWh} \mathrm{m}^{-2}$ year ${ }^{-1}$ of electricity demand (Table 4 ). The present PV blind would partially compensate such greater demands.

As estimated in Figure 14, this system would produce a surplus of electricity in high-insolation greenhouses, which demand several kilowatt hours per square meter per year of electricity. In addition, Figure $6 \mathrm{~b}$ suggests that external installation would greatly improve electricity production. For these reasons, externally mounted PV blinds with less PV cell density might compensate electricity demands of conventional greenhouses in high-insolation regions. The decreased cell density is expected to increase agronomic sustainability for greenhouse crop cultivation. Waterproofing and mechanical reliability against severe weather conditions should be included with these systems to be installed externally. However, in very high-irradiation regions, a higher PV cell density might be acceptable. This might result in higher electricity production for greater load operations with moderate shading inside the greenhouse.

To apply the present PV blind systems to actual scale greenhouses, decreasing the PV module production costs is absolutely necessary by manufacturing automation. The PV module production cost, because of its current hand-made manufacturing process, is extremely expensive, such that it cannot be compensated by the value of the PV producible electricity. The other components of the blind systems, including the control circuit parts, are readily available from the market with reasonable prices.

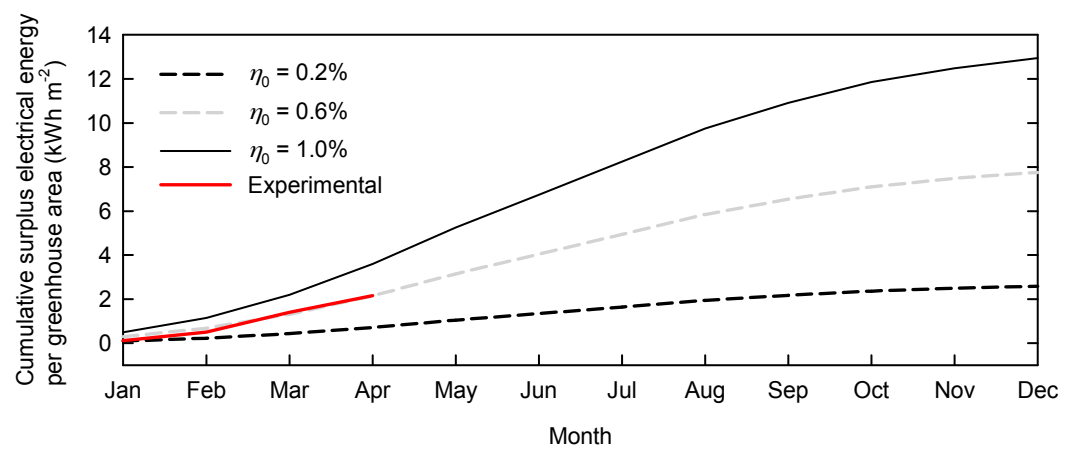

Figure 14. Calculated surplus electrical energy of the PV blind per unit greenhouse area estimated based on local insolation statistics, assuming $\eta_{0}$ of $0.2,0.6$, and $1.0 \%$. The experimentally obtained surplus energy is also depicted. 
Table 4. Annual electrical energy demand per unit greenhouse area at different locations with various electrical loads.

\begin{tabular}{cccc}
\hline Location & Electrical Load & $\begin{array}{c}\text { Energy Demand } \\
\left(\mathbf{k W h ~ m}^{-\mathbf{2}} \mathbf{Y e a r}^{-\mathbf{1}} \mathbf{)}\right.\end{array}$ & Reference \\
\hline Japan & side-ventilation controller & 0.1 & {$[70,71]$} \\
\hline Northern Europe & $\begin{array}{c}\text { typical electricity consumption in northern } \\
\text { European greenhouses }\end{array}$ & $2-7$ & {$[38]$} \\
\hline Mediterranean & heating, cooling, ventilation & $2-9$ & {$[74]$} \\
\hline Spain & window operation, pumps & $3{ }^{*}$ & {$[29]$} \\
\hline Spain & $\begin{array}{c}\text { fans, irrigation and fertilization equipment, fuel } \\
\text { burner, window-opening and screen motors, } \\
\text { automatism for climate control, compressor, } \\
\text { electrical resistance of the fuel reservoir }\end{array}$ & 7 & {$[72]$} \\
\hline Greece & ventilation, cooling, lighting & 20 & {$[44]$} \\
\hline Greece & low-level energy consumption greenhouse & 25 & {$[33]$} \\
\hline China & cooling and ventilation & 30 & {$[75]$} \\
\hline Saudi Arabia & fans, cooling pump, PC & 56 & {$[6]$} \\
\hline
\end{tabular}

The shading percentage of the PV blind was $40 \%$ at $\theta=0^{\circ}$ inclination. Shading affects the crop growth, the yield, and the choice of the greenhouse species that can be cultivated underneath the PV panels. Some reports of earlier studies have described crop growth under certain levels of PV shading. Wild rocket crops were cultivated properly in an Italian greenhouse under a PV panel installation that provided 32\% roof coverage [35]. Under 50\% coverage of a greenhouse roof by PV cells arranged in a checkerboard formation, lettuce was cultivated during summer and autumn in Japan [31]. Specific translucent film was placed underneath the solar cells in their test greenhouse. The film assisted scattering of light impinged across PV cell intervals to wider area of crops below [31]. More recently, the qualities of berries cultivated under the PV modules, which covered $32 \%$ of the greenhouse roof, were investigated in Italy [76]. Reportedly, the concentrations of total anthocyanins and total phenols in raspberry and blackberry fruits grown under the PV shading were greater than those of the control berries grown in the conventional greenhouse. These results of earlier studies suggest that controlled shading by the semi-transparent PV blind might be beneficial for the cultivation of some crop species.

The concept of shading percentage of the see-through PV modules used in the present study differed from that of opaque planar PV cells installed in other PV greenhouses. The installation of conventional planar PV cells on a greenhouse roof casts a distinct shadow area on the ground in the greenhouse. The shadow area is dark without direct sunlight, the remaining area is bright. As the earth rotates, the shadow moves in the greenhouse. Accordingly, plants at a fixed position in the greenhouse are irradiated with fluctuating intensities of sunlight [20]. By contrast, see-through semi-transparency of $40 \%$ shading does not cast explicit shadow patterns in the greenhouse. Instead, part of the apparent sun area seen from plants is eclipsed by the micro PV cells $[26,27,55]$. The remaining part of direct sunlight beam can irradiate plants. In addition, the dynamic shading control of the present PV blind enables moderate shading only during high-insolation hours. Yield and quality of some crop species might be improved if the excessive sunlight were partly shaded by the semi-transparent PV blinds, or if the blind rotates when irradiance is less than the threshold level, letting more sunlight irradiate the plants.

Figure 15 depicts the calculated solar energy inside the PV blind greenhouse with the north-south ridge orientation assuming that the entire roof was covered with the PV blinds and that the sunlight transmittance of the PV module is $0 \%$ at $\theta=90^{\circ}$ and $60 \%$ at $\theta=0^{\circ}$. Eight-percent of the sky would be covered with the PV modules of $0 \%$ transmittance at $\theta=90^{\circ}$ according to the geometry 
calculation presented in Figure 15a. Cloudless sky with atmospheric transmittance of 0.65 was assumed. Solar energy was shown as parameters of threshold $I_{\mathrm{H}}$ levels for the PV blind turns. For that calculation, the total sunlight transmittance of overlapping greenhouse glazing and the PV blind was assumed to be $51 \%$ (Figure $8 \mathrm{c}$ ) when $\theta=0^{\circ}$. It was assumed to be $78 \%$ ( $=0.85$ of glazing transmittance $\times 0.92$ of unshaded zone as depicted in Figure $15 \mathrm{a} \times 100 \%$ ) when $\theta=90^{\circ}$. As the threshold $I_{\mathrm{H}}$ value for the blind operation increases, solar energy in the greenhouse increases. As presented in Table 5 , the annual solar energy in the greenhouse would be $59 \%$ of that outside if the threshold $I_{\mathrm{H}}$ was set at $500 \mathrm{~W} \mathrm{~m}^{-2}$. It would increase to $73 \%$ if the threshold $I_{\mathrm{H}}$ was set at $900 \mathrm{~W} \mathrm{~m}^{-2}$. By contrast, electricity generation would decrease as the threshold $I_{\mathrm{H}}$ increases. Compared with the annual solar energy received in the greenhouse without the PV blind installation, $70 \%, 77 \%$, and $86 \%$ of solar energy would be received in the PV blind greenhouse with the set threshold $I_{\mathrm{H}} \mathrm{s}$ of 500,700 , and $900 \mathrm{~W} \mathrm{~m}^{-2}$, respectively. Figure 14 shows an estimation of $7.8 \mathrm{kWh} \mathrm{m}^{-2}$ year ${ }^{-1}$ of electrical energy production for $\eta_{0}=0.6 \%$, although the greenhouse crops receive $1170 \mathrm{kWh} \mathrm{m}^{-2}$ year $^{-1}$ if threshold $I_{\mathrm{H}}$ is set at $500 \mathrm{~W} \mathrm{~m}^{-2}$ (Figure 15b). Incorporating the actual sky conditions (2009-2017, Japan Meteorological Agency) into calculations, $1170 \mathrm{kWh} \mathrm{m}^{-2}$ year ${ }^{-1}$ is declined to $765 \mathrm{kWh} \mathrm{m}^{-2}$ year $^{-1}$. Assuming that $1 \%$ of the solar energy can be converted into plant biomass $[77,78]$, the solar-energy use ratio for plant biomass production to electricity production would be approximately $1: 1$ under $\eta_{0}=0.6 \%$ estimation. To validate the estimation, plant growth under the PV blinds should be investigated in future experiments.

Table 5. Estimated annual solar energy in the north-south oriented greenhouse equipped with the PV blind entirely covering the roof with three threshold irradiance values for the PV blind operation.

\begin{tabular}{|c|c|c|c|c|c|}
\hline & \multirow{4}{*}{ Outside } & \multicolumn{4}{|c|}{ Inside the Greenhouse ** } \\
\hline & & \multirow{3}{*}{ Without PV Blind } & \multirow{2}{*}{\multicolumn{3}{|c|}{$\begin{array}{c}\text { PV Blind Overlapped with Glazing Roof } \\
\text { Threshold } I_{\mathrm{H}}\left(\mathrm{W} \mathrm{m}^{-2}\right)\end{array}$}} \\
\hline & & & & & \\
\hline & & & 500 & 700 & 900 \\
\hline $\mathrm{kWh} \mathrm{m}^{-2}$ year $^{-1} *$ & 1976 & 1679 & 1170 & 1292 & 1439 \\
\hline$\%$ outside & 100 & 85 & 59 & 65 & 73 \\
\hline $\begin{array}{l}\% \text { interior greenhouse } \\
\text { without the PV blind }\end{array}$ & 118 & 100 & 70 & 77 & 86 \\
\hline
\end{tabular}

* Solar energy was calculated assuming cloudless sky conditions along with atmospheric transmissivity of 0.65 .

** Transmittance of the greenhouse glazing was assumed to be 0.85 (greenhouse frames were omitted).

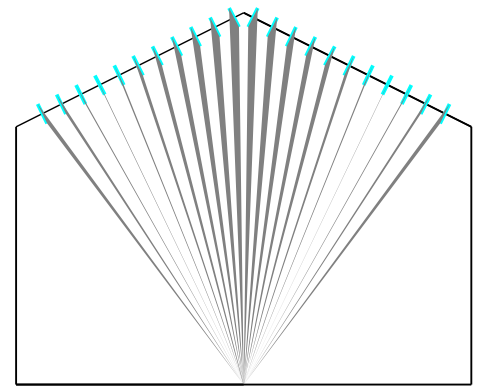

(a)

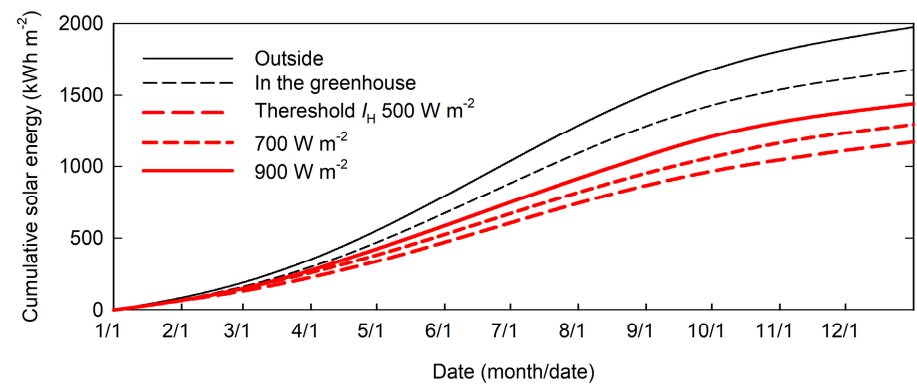

(b)

Figure 15. Estimated cumulative solar energy in the north-south oriented greenhouse equipped with a PV blind entirely covering the roof: (a) the shading zones by the PV blinds were painted in gray assuming that the sunlight transmittance of the PV module at $\theta=90^{\circ}$ is 0 ; (b) the thresholds $I_{\mathrm{H}^{s}}$ were chosen at the three levels of 500,700 , and $900 \mathrm{~W} \mathrm{~m}^{-2}$. The transmittance of the greenhouse glazing and the blind at parallel and perpendicular positions were assumed as $85 \%, 60 \%$, and $92 \%$ ( $8 \%$ is PV shadow as depicted in (a)), respectively. Cloudless sky with atmospheric transmittance of 0.65 was assumed. For comparison, solar energy outside the greenhouse and inside the greenhouse without PV blinds (greenhouse frames were omitted) are also presented. 


\section{Conclusions}

A semi-transparent PV blind system was prototyped based on micro-spherical solar cell technology for application to greenhouse shading control. The PV blind inclination had been altered autonomously according to the set points of the irradiance threshold values that were adjustable by a grower by modulating the variable resistor value in the control circuit. The cumulative energy balance of the PV blind system became positive after the five-month operation test during winter to spring on the west coast of Japan. This result suggests that the surplus electrical energy is useful for greenhouse environment management to achieve better crop yield and quality with the mitigation of fuel and grid electricity consumption, particularly in high-insolation regions. Assuming that $1 \%$ of the solar energy can be converted into plant biomass, the solar-energy use ratio for plant biomass production to electricity production would be approximately 1:1 using the present PV blind system at the greenhouse under the actual sky condition. That ratio is adjustable by the set-point of the threshold irradiance for the blind rotations. This performance might provide a new strategic cultivation opportunity to growers. Although this system is still a prototype, the obtained experimental data clearly indicate that the concept of the semi-transparent PV blind system for application to greenhouses is sufficiently valuable to be tested further for its feasibility, including effects on crop yield and quality.

Supplementary Materials: The following are available online at http:/ / www.mdpi.com/1996-1073/11/7/1681/s1, Video S1: 2 March 2018 blind operation.

Author Contributions: Conceptualization, Z.L., A.Y., M.C., H.Y., I.K. and Y.I.; Data curation, Z.L. and A.Y.; Formal analysis, Z.L. and A.Y.; Funding acquisition, A.Y.; Investigation, Z.L. and A.Y.; Methodology, Z.L. and A.Y.; Project administration, A.Y.; Supervision, A.Y., H.Y., I.K. and Y.I.; Validation, Z.L. and A.Y.; Visualization, Z.L. and A.Y.; Writing—original draft, Z.L. and A.Y.; Writing—review \& editing, M.C., H.Y., I.K. and Y.I.

Funding: This research was funded by JSPS KAKENHI grant numbers (C) 15K07667 and (C) 18K05903.

Acknowledgments: The authors thank Sphelar Power Corporation (Kyoto, Japan) for fabricating the see-through semi-transparent PV modules. We thank Makoto Ueno of Shimane University for permission to use the test greenhouse. We also thank Tetsuo Matsuoka of Shimane University for his assistance during basic experiments.

Conflicts of Interest: The authors declare no conflict of interest. The founding sponsors had no role in the design of the study; in the collection, analyses, or interpretation of data; in the writing of the manuscript; and in the decision to publish the results.

\section{References}

1. Dias, G.M.; Ayer, N.W.; Khosla, S.; Acker, R.V.; Young, S.B.; Whitney, S.; Hendricks, P. Life cycle perspectives on the sustainability of Ontario greenhouse tomato production: Benchmarking and improvement opportunities. J. Clean Prod. 2017, 140, 831-839. [CrossRef]

2. Ntinas, G.K.; Neumair, M.; Tsadilas, C.D.; Meyer, J. Carbon footprint and cumulative energy demand of greenhouse and open-field tomato cultivation systems under Southern and Central European climatic conditions. J. Clean Prod. 2017, 142, 3617-3626. [CrossRef]

3. Cuce, E.; Harjunowibowo, D.; Cuce, P.M. Renewable and sustainable energy saving strategies for greenhouse systems: A comprehensive review. Renew. Sustain. Energy Rev. 2016, 64, 34-59. [CrossRef]

4. Hassanien, R.H.E.; Li, M.; Lin, W.D. Advanced applications of solar energy in agricultural greenhouses. Renew. Sustain. Energy Rev. 2016, 54, 989-1001. [CrossRef]

5. Squatrito, R.; Sgroi, F.; Tudisca, S.; Trapani, A.M.D.; Testa, R. Post Feed-in scheme photovoltaic system feasibility evaluation in Italy: Sicilian case studies. Energies 2014, 7, 7147-7165. [CrossRef]

6. Al-Ibrahim, A.; Al-Abbadi, N.; Al-Helal, I. PV greenhouse system-System description, performance and lesson learned. Acta Hortic. 2006, 710, 251-264. [CrossRef]

7. Juang, P.; Kacira, M. System dynamics of a photovoltaic integrated greenhouse. Acta Hortic. 2014, 1037, 107-112. [CrossRef]

8. Al-Shamiry, F.M.S.; Ahmad, D.; Sharif, A.R.M.; Aris, I.; Janius, R.; Kamaruddin, R. Design and development of a photovoltaic power system for tropical greenhouse cooling. Am. J. Appl. Sci. 2007, 4, 386-389. [CrossRef]

9. Blanco, I.; Anifantis, A.S.; Pascuzzi, S.; Mugnozza, G.S. Hydrogen and renewable energy sources integrated system for greenhouse heating. J. Agric. Eng. Res. 2013, 44. [CrossRef] 
10. Russo, G.; Anifantis, A.S.; Verdiani, G.; Mugnozza, G.S. Environmental analysis of geothermal heat pump and LPG greenhouse heating systems. Biosyst. Eng. 2014, 127, 11-23. [CrossRef]

11. Martínez, D.L.V.; Ureña, L.J.B.; Aiz, F.D.M.; Martínez, A.L. Greenhouse Agriculture in Almería. A Comprehensive Techno-Economic Analysis; Cajamar Caja Rural: Andalusia, Spain, 2016; ISBN 9788495531759.

12. Abdel-Ghany, A.M.; Picuno, P.; Al-Helal, I.; Alsadon, A.; Ibrahim, A.; Shady, M. Radiometric characterization, solar and thermal radiation in a greenhouse as affected by shading configuration in an arid climate. Energies 2015, 8, 13928-13937. [CrossRef]

13. Yano, A.; Furue, A.; Moriyama, T.; Ide, O.; Tsuchiya, K. Development of a greenhouse shading screen controller driven by photovoltaic energy. J. Jpn. Soc. Agric. Mach. 2007, 69, 57-64.

14. García, M.L.; Medrano, E.; Sánchez-Guerrero, M.C.; Lorenzo, P. Climatic effects of two cooling systems in greenhouses in the Mediterranean area: External mobile shading and fog system. Biosyst. Eng. 2011, 108, 133-143. [CrossRef]

15. López-Marín, J.; Gálvez, A.; González, A.; Egea-Gilabert, C.; Fernández, J.A. Effect of shade on yield, quality and photosynthesis-related parameters of sweet pepper plants. Acta Hortic. 2012, 956, 545-552. [CrossRef]

16. Lorenzo, P.; Sánchez-Guerrero, M.C.; Medrano, E.; García, M.L.; Caparrós, I.; Giménez, M. External greenhouse mobile shading: Effect on microclimate, water use efficiency and yield of a tomato crop grown under different salinity levels of the nutrient solution. Acta Hortic. 2003, 609, 181-186. [CrossRef]

17. Ahemd, H.A.; Al-Faraj, A.A.; Abdel-Ghany, A.M. Shading greenhouses to improve the microclimate, energy and water saving in hot regions: A review. Sci. Hortic. 2016, 201, 36-45. [CrossRef]

18. Aroca-Delgado, R.; Pérez-Alonso, J.; Callejón-Ferre, A.J.; Velázquez-Martí, B. Compatibility between crops and solar panels: An overview from shading systems. Sustainability 2018, 10, 743. [CrossRef]

19. Mashonjowa, E.; Ronsse, F.; Mhizha, T.; Milford, J.R.; Lemeur, R.; Pieters, J.G. The effects of whitening and dust accumulation on the microclimate and canopy behaviour of rose plants (Rosa hybrida) in a greenhouse in Zimbabwe. Sol. Energy 2010, 84, 10-23. [CrossRef]

20. Yano, A.; Kadowaki, M.; Furue, A.; Tamaki, N.; Tanaka, T.; Hiraki, E.; Kato, Y.; Ishizu, F.; Noda, S. Shading and electrical features of a photovoltaic array mounted inside the roof of an east-west oriented greenhouse. Biosyst. Eng. 2010, 106, 367-377. [CrossRef]

21. Pérez-Alonso, J.; Pérez-García, M.; Pasamontes-Romera, M.; Callejón-Ferre, A.J. Performance analysis and neural modelling of a greenhouse integrated photovoltaic system. Renew. Sustain. Energy Rev. 2012, 16, 4675-4685. [CrossRef]

22. Fatnassi, H.; Poncet, C.; Bazzano, M.M.; Brun, R.; Bertin, N. A numerical simulation of the photovoltaic greenhouse microclimate. Sol. Energy 2015, 120, 575-584. [CrossRef]

23. Marucci, A.; Monarca, D.; Colantoni, A.; Campiglia, E.; Cappuccini, A. Analysis of the internal shading in a photovoltaic greenhouse tunnel. J. Agric. Eng. 2017, 48. [CrossRef]

24. Marucci, A.; Zambon, I.; Colantoni, A.; Monarca, D. A combination of agricultural and energy purposes: Evaluation of a prototype of photovoltaic greenhouse tunnel. Renew. Sustain. Energy Rev. 2018, 82, 1178-1186. [CrossRef]

25. Colantoni, A.; Monarca, D.; Marucci, A.; Cecchini, M.; Zambon, I.; Battista, F.D.; Maccario, D.; Saporito, M.G.; Beruto, M. Solar radiation distribution inside a greenhouse prototypal with photovoltaic mobile plant and effects on flower growth. Sustainability 2018, 10, 855. [CrossRef]

26. Yano, A.; Onoe, M.; Nakata, J. Prototype semi-transparent photovoltaic modules for greenhouse roof applications. Biosyst. Eng. 2014, 122, 62-73. [CrossRef]

27. Cossu, M.; Yano, A.; Li, Z.; Onoe, M.; Nakamura, H.; Matsumoto, T.; Nakata, J. Advances on the semi-transparent modules based on micro solar cells: First integration in a greenhouse system. Appl. Energy 2016, 162, 1042-1051. [CrossRef]

28. Kadowaki, M.; Yano, A.; Ishizu, F.; Tanaka, T.; Noda, S. Effects of greenhouse photovoltaic array shading on Welsh onion growth. Biosyst. Eng. 2012, 111, 290-297. [CrossRef]

29. Ureña-Sánchez, R.; Callejón-Ferre, Á.J.; Pérez-Alonso, J.; Carreño-Ortega, Á. Greenhouse tomato production with electricity generation by roof-mounted flexible solar panels. Sci. Agric. 2012, 69, 233-239. [CrossRef]

30. Hassanien, R.H.E.; Li, M.; Yin, F. The integration of semi-transparent photovoltaics on greenhouse roof for energy and plant production. Renew. Energy 2018, 121, 377-388. [CrossRef]

31. Tani, A.; Shiina, S.; Nakashima, K.; Hayashi, M. Improvement in lettuce growth by light diffusion under solar panels. J. Agric. Meteorol. 2014, 70, 139-149. [CrossRef] 
32. Hassanien, R.H.E.; Li, M. Influences of greenhouse-integrated semi-transparent photovoltaics on microclimate and lettuce growth. Int. J. Agric. Biol. Eng. 2017, 10, 11-22. [CrossRef]

33. Tripanagnostopoulos, G.; Kavga, A.; Souliotis, M.; Tripanagnostopoulos, Y. Greenhouse performance results for roof installed photovoltaics. Renew. Energy 2017, 111, 724-731. [CrossRef]

34. Kavga, A.; Trypanagnostopoulos, G.; Zervoudakis, G.; Tripanagnostopoulos, Y. Growth and physiological characteristics of lettuce (Lactuca sativa L.) and Rocket (Eruca sativa Mill.) plants cultivated under photovoltaic panels. Not. Bot. Horti Agrobot. 2018, 46, 206-212. [CrossRef]

35. Buttaro, D.; Renna, M.; Gerardi, C.; Blando, F.; Santamaria, P.; Serio, F. Soilless production of wild rocket as affected by greenhouse coverage with photovoltaic module. Acta Sci. Pol. Hortorum Cultus 2016, 15, 129-142.

36. Sonneveld, P.J.; Swinkels, G.L.A.M.; Bot, G.P.A.; Flamand, G. Feasibility study for combining cooling and high grade energy production in a solar greenhouse. Biosyst. Eng. 2010, 105, 51-58. [CrossRef]

37. Sonneveld, P.J.; Swinkels, G.L.A.M.; Campen, J.; van Tuijl, B.A.J.; Janssen, H.J.J.; Bot, G.P.A. Performance results of a solar greenhouse combining electrical and thermal energy production. Biosyst. Eng. 2010, 106, 48-57. [CrossRef]

38. Emmott, C.J.M.; Röhr, J.A.; Campoy-Quiles, M.; Kirchartz, T.; Urbina, A.; Ekins-Daukes, N.J.; Nelson, J. Organic photovoltaic greenhouses: A unique application for semi-transparent PV? Energy Environ. Sci. 2015, 8, 1317-1328. [CrossRef]

39. Yang, F.; Zhang, Y.; Hao, Y.; Cui, Y.; Wang, W.; Ji, T.; Shi, F.; Wei, B. Visibly transparent organic photovoltaic with improved transparency and absorption based on tandem photonic crystal for greenhouse application. Appl. Opt. 2015, 54, 10232-10239. [CrossRef] [PubMed]

40. Dos Reis Benatto, G.A.; Corazza, M.; Roth, B.; Schütte, F.; Rengenstein, M.; Gevorgyan, S.A.; Krebs, F.C. Inside or outside? Linking outdoor and indoor lifetime tests of ITO-free organic photovoltaic devices for greenhouse applications. Energy Technol. 2017, 5, 338-344. [CrossRef]

41. Kim, J.-J.; Kang, M.; Kwak, O.K.; Yoon, Y.-J.; Min, K.S.; Chu, M.-J. Fabrication and characterization of dye-sensitized solar cells for greenhouse application. Int. J. Photoenergy 2014, 2014, 376315. [CrossRef]

42. Allardyce, C.S.; Fankhauser, C.; Zakeeruddin, S.M.; Grätzel, M.; Dyson, P.J. The influence of greenhouse-integrated photovoltaics on crop production. Sol. Energy 2017, 155, 517-522. [CrossRef]

43. Liu, W.; Liu, L.; Guan, C.; Zhang, F.; Li, M.; Lv, H.; Yao, P.; Ingenhoff, J. A novel agricultural photovoltaic system based on solar spectrum separation. Sol. Energy 2018, 162, 84-94. [CrossRef]

44. Souliotis, M.; Tripanagnostopoulos, Y.; Kavga, A. The use of Fresnel lenses to reduce the ventilation needs of greenhouses. Acta Hortic. 2006, 719, 107-114. [CrossRef]

45. Sonneveld, P.J.; Swinkels, G.L.A.M.; van Tuijl, B.A.J.; Janssen, H.J.J.; Campen, J.; Bot, G.P.A. Performance of a concentrated photovoltaic energy system with static linear Fresnel lenses. Sol. Energy 2011, 85, 432-442. [CrossRef]

46. Vadiee, A.; Martin, V. Solar blind system-Solar energy utilization and climate mitigation in glassed buildings. Energy Procedia 2014, 57, 2023-2032. [CrossRef]

47. Vadiee, A.; Yaghoubi, M. Enviro-economic assessment of energy conservation methods in commercial greenhouses in Iran. Outlook Agric. 2016, 45, 47-53. [CrossRef]

48. Vadiee, A.; Yaghoubi, M. Exergy analysis of the solar blind system integrated with a commercial solar greenhouse. Int. J. Renew. Energy Res. 2016, 6, 1189-1199.

49. Vadiee, A.; Yaghoubi, M.; Martin, V.; Bazargan-Lari, Y. Energy analysis of solar blind system concept using energy system modelling. Sol. Energy 2016, 139, 297-308. [CrossRef]

50. Marucci, A.; Monarca, D.; Cecchini, M.; Colantoni, A.; Cappuccini, A. Analysis of internal shading degree to a prototype of dynamics photovoltaic greenhouse through simulation software. J. Agric. Eng. 2015, 46. [CrossRef]

51. Marucci, A.; Cappuccini, A. Dynamic photovoltaic greenhouse: Energy efficiency in clear sky conditions. Appl. Energy 2016, 170, 362-376. [CrossRef]

52. Marucci, A.; Cappuccini, A. Dynamic photovoltaic greenhouse: Energy balance in completely clear sky condition during the hot period. Energy 2016, 102, 302-312. [CrossRef]

53. Green, M.A.; Hishikawa, Y.; Warta, W.; Dunlop, E.D.; Levi, D.H.; Hohl-Ebinger, J.; Ho-Baillie, A.W.Y. Solar cell efficiency tables (version 50). Prog. Photovolt. Res. Appl. 2017, 25, 668-676. [CrossRef]

54. Al Dakheel, J.; Aoul, K.T. Building applications, opportunities and challenges of active shading systems: A state-of-the-art review. Energies 2017, 10, 1672. [CrossRef] 
55. Li, Z.; Yano, A.; Cossu, M.; Yoshioka, H.; Kita, I.; Ibaraki, Y. Shading and electric performance of a prototype greenhouse blind system based on semi-transparent photovoltaic technology. J. Agric. Meteorol. 2018, in press.

56. Biancardo, M.; Taira, K.; Kogo, N.; Kikuchi, H.; Kumagai, N.; Kuratani, N.; Inagawa, I.; Imoto, S.; Nakata, J. Characterization of microspherical semi-transparent solar cells and modules. Sol. Energy 2007, 81, 711-716. [CrossRef]

57. Taira, K.; Nakata, J. Silicon cells: Catching rays. Nat. Photonics Technol. Focus 2010, 4, 602-603. [CrossRef]

58. Yano, A.; Furue, A.; Kadowaki, M.; Tanaka, T.; Hiraki, E.; Miyamoto, M.; Ishizu, F.; Noda, S. Electrical energy generated by photovoltaic modules mounted inside the roof of a north-south oriented greenhouse. Biosyst. Eng. 2009, 103, 228-238. [CrossRef]

59. Tudisca, S.; Trapani, A.M.D.; Sgroi, F.; Testa, R.; Squatrito, R. Assessment of Italian energy policy through the study of a photovoltaic investment on greenhouse. Afr. J. Agric. Res. 2013, 8, 3089-3096. [CrossRef]

60. Sgroi, F.; Tudisca, S.; Trapani, A.M.D.; Testa, R.; Squatrito, R. Efficacy and efficiency of Italian energy policy: The case of PV systems in greenhouse farms. Energies 2014, 7, 3985-4001. [CrossRef]

61. Cossu, M.; Ledda, L.; Deligios, P.A.; Sirigu, A.; Murgia, L.; Pazzona, A.; Yano, A. Solar light distribution inside a greenhouse with the roof area entirely covered with photovoltaic panels. Acta Hortic. 2017, 1182, 47-55. [CrossRef]

62. Castellano, S.; Santamaria, P.; Serio, F. Solar radiation distribution inside a monospan greenhouse with the roof entirely covered by photovoltaic panels. J. Agric. Eng. 2016, 47. [CrossRef]

63. Castellano, S. Photovoltaic greenhouses: Evaluation of shading effect and its influence on agricultural performances. J. Agric. Eng. 2014, 45. [CrossRef]

64. Castellano, S. Influence of geometry on shading effect inside photovoltaic greenhouses. Acta Hortic. 2017, 1170, 813-819. [CrossRef]

65. Cossu, M.; Murgia, L.; Ledda, L.; Deligios, P.A.; Sirigu, A.; Chessa, F.; Pazzona, A. Solar radiation distribution inside a greenhouse with south-oriented photovoltaic roofs and effects on crop productivity. Appl. Energy 2014, 133, 89-100. [CrossRef]

66. Cossu, M.; Ledda, L.; Urracci, G.; Sirigu, A.; Cossu, A.; Murgia, L.; Pazzona, A.; Yano, A. An algorithm for the calculation of the light distribution in photovoltaic greenhouses. Sol. Energy 2017, 141, 38-48. [CrossRef]

67. Cossu, M.; Yano, A.; Murgia, L.; Ledda, L.; Deligios, P.A.; Sirigu, A.; Chessa, F.; Pazzona, A. Effects of the photovoltaic roofs on the greenhouse microclimate. Acta Hortic. 2017, 1170, 461-468. [CrossRef]

68. Xue, J. Photovoltaic agriculture-New opportunity for photovoltaic applications in China. Renew. Sustain. Energy Rev. 2017, 73, 1-9. [CrossRef]

69. Japan Meteorological Agency: Monthly Mean Global Solar Radiation. Available online: http:/ / www.data. jma.go.jp/obd/stats/etrn/view/monthly_s3_en.php?block_no=47741\&view=11 (accessed on 1 March 2018).

70. Yano, A.; Tsuchiya, K.; Nishi, K.; Moriyama, T.; Ide, O.; Ishizaka, A.; Toya, M. Development of a power saving greenhouse side window controller driven by photovoltaic energy. J. Jpn. Soc. Agric. Mach. 2005, 67, 100-110.

71. Yano, A.; Tsuchiya, K.; Nishi, K.; Moriyama, T.; Ide, O. Development of a greenhouse side-ventilation controller driven by photovoltaic energy. Biosyst. Eng. 2007, 96, 633-641. [CrossRef]

72. Rocamora, M.C.; Tripanagnostopoulos, Y. Aspects of PV/T solar system application for ventilation needs in greenhouses. Acta Hortic. 2006, 719, 239-246. [CrossRef]

73. Carreño-Ortega, A.; Galdeano-Gómez, E.; Pérez-Mesa, J.C.; Galera-Quiles, M.D.C. Policy and environmental implications of photovoltaic systems in farming in southeast Spain: Can greenhouses reduce the greenhouse effect? Energies 2017, 10, 761. [CrossRef]

74. Campiotti, C.; Dondi, F.; Genovese, A.; Alonzo, G.; Catanese, V.; Incrocci, L.; Bibbiani, C. Photovoltaic as sustainable energy for greenhouse and closed plant production system. Acta Hortic. 2008, 797, 373-378. [CrossRef]

75. Wang, T.; Wu, G.; Chen, J.; Cui, P.; Chen, Z.; Yan, Y.; Zhang, Y.; Li, M.; Niu, D.; Li, B.; et al. Integration of solar technology to modern greenhouse in China: Current status, challenges and prospect. Renew. Sustain. Energy Rev. 2017, 70, 1178-1188. [CrossRef]

76. Blando, F.; Gerardi, C.; Renna, M.; Castellano, S.; Serio, F. Characterisation of bioactive compounds in berries from plants grown under innovative photovoltaic greenhouses. J. Berry Res. 2018, 8, 55-69. [CrossRef] 
77. Melis, A. Solar energy conversion efficiencies in photosynthesis: Minimizing the chlorophyll antennae to maximize efficiency. Plant Sci. 2009, 177, 272-280. [CrossRef]

78. Zhu, X.-G.; Long, S.P.; Ort, D.R. Improving photosynthetic efficiency for greater yield. Ann. Rev. Plant Biol. 2010, 61, 235-261. [CrossRef] [PubMed] 